\section{To: (Receiving organization)} Distribution

5. Proj./Prog./Dept./Div.:

$W-441$

8. Originator Remarks:

Approval and Release
3. From: (Originating Organization) Process Design (8C453)

6. Design Authority/ Design Agent/Cog. Engr.: J. J. Irwin

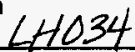

4. Related EDT No.:

$\mathrm{N} / \mathrm{A}$

7. Purchase Order No.:

$\mathrm{N} / \mathrm{A}$

9. Equip./Component No.: $\mathrm{N} / \mathrm{A}$

10. System/Bldg./Facility:

SNF Cold Vacuum Drying Facility

11. Receiver Remarks: 11A. Design Baseline Document? Yes [] No

12. Major Assm. Dwg. No.:

N/A

13. Permit/Permit Application No.: $N / A$

14. Required Response Date: $\mathrm{N} / \mathrm{A}$

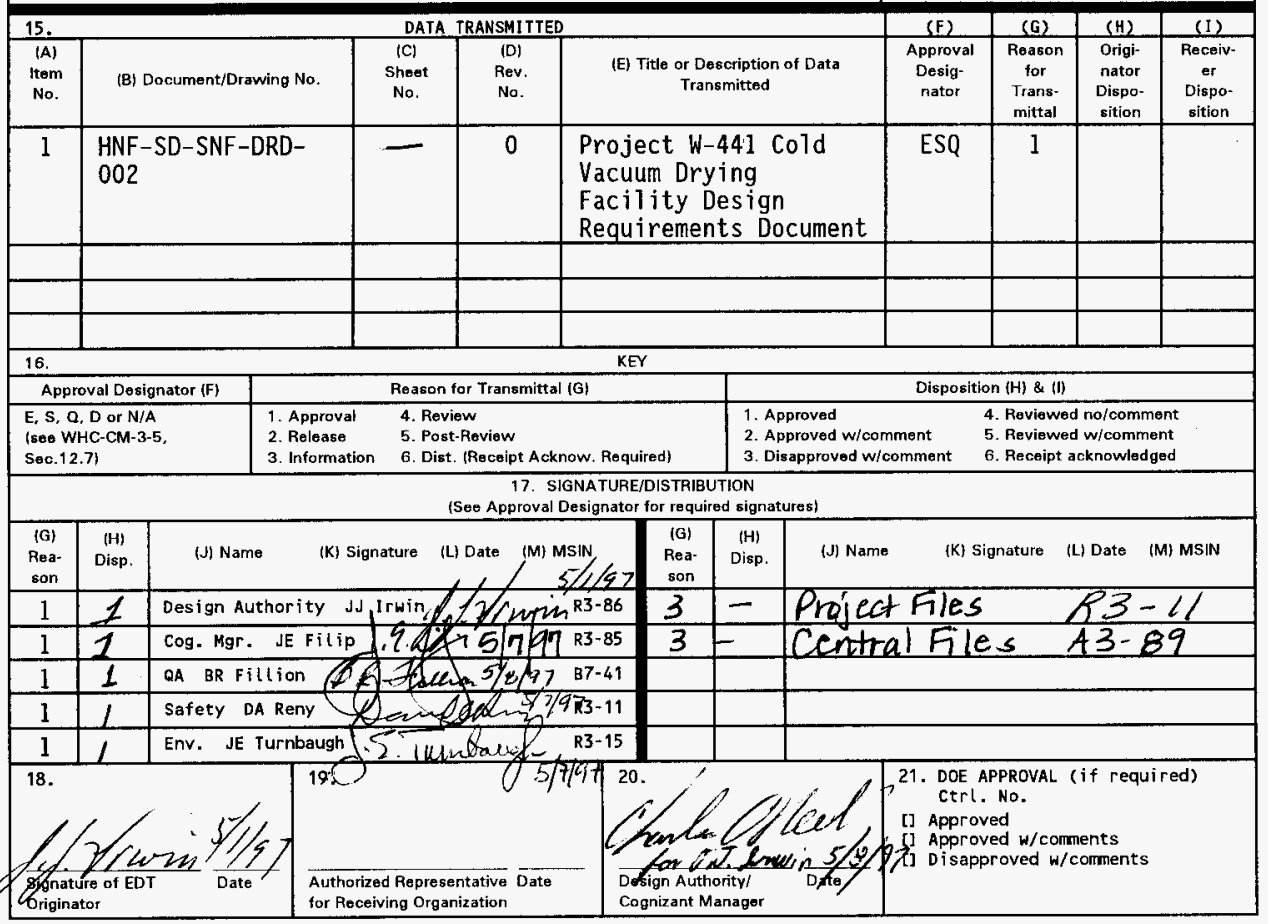

BD $-7400-172-2(05 / 96)$ GEF097 


\title{
Project W-441 Cold Vacuum Drying Facility Design Requirements Document
}

\author{
J. E. Filip
}

Numatec Hanford Corporation, Richland, WA 99352

U.S. Department of Energy Contract DE-AC06-96RL13200

EDT/ECN: 618634

Org Code: $8 \mathrm{C} 800$

UC: 510

B\&R Code: 39EW70400

Charge Code: LH034

Total Pages: 85

Key Words: SNF, CVDF, MCO

Abstract: This document has been prepared and is being released for Project $W-441$ to record the design basis for the design of the Cold Vacuum Drying Facility. This document sets forth the physical design criteria, Codes and Standards, and functional requirements that were used in the design of the Cold Vacuum Drying Facility.

This document contains section 3,4,6, and 9 of the cold Vacuum Drying Facility Design Requirements Document. The remaining sections will be issued at a later date.

TRADEMARK DISCLAIMER. Reference herein to any specific comercial product, process, or service by trade name, trademark, manufacturer, or otherwise, does not necessarily constitute or imply its endorsement, recommendation, or favoring by the United States Government or any agency thereof or its contractors or subcontractors.

Printed in the United States of America. To obtain copies of this document, contact: Document Control Services, P.O. Box 950, Mailstop H6-08, Richland WA 99352, Phone (509) 372-2420; Fax (509) 376-4989.
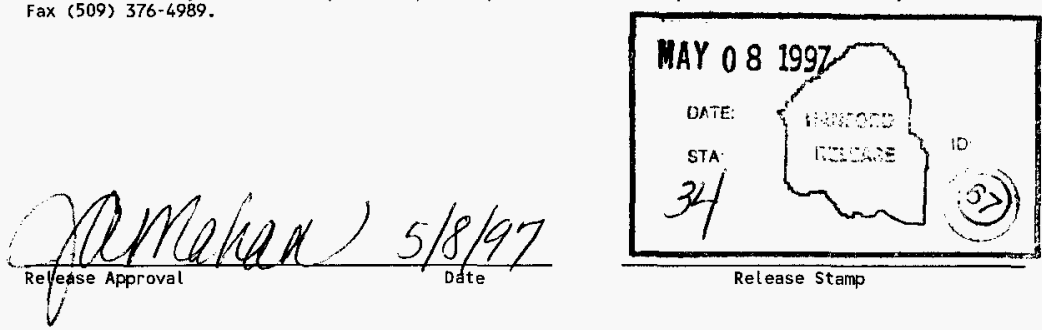

Release Stamp

Approved for Public Release 


\section{CONTENTS}

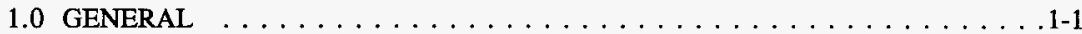

1.1 INTRODUCTION . . . . . . . . . . . . . . . .1-1

1.2 REFERENCE CODES AND STANDARDS $\ldots \ldots \ldots \ldots \ldots \ldots \ldots 1$-1

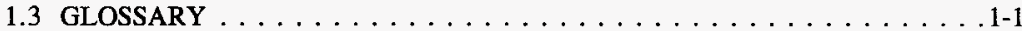

2.0 SITE DEVELOPMENT $\ldots \ldots \ldots \ldots \ldots \ldots \ldots \ldots \ldots \ldots \ldots \ldots \ldots \ldots \ldots$

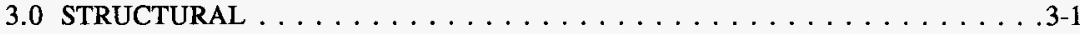

3.1 GENERAL $\ldots \ldots \ldots \ldots \ldots \ldots \ldots \ldots \ldots \ldots \ldots \ldots \ldots \ldots \ldots \ldots \ldots$

3.1.1 Structural Systems $\ldots \ldots \ldots \ldots \ldots \ldots \ldots \ldots \ldots \ldots . \ldots \ldots$.1

3.1.2 CVDF Design Life Requirement . . . . . . . . . . . . . . 3-1

3.1.3 Structural Design for Demolition . . . . . . . . . . . . . 3-1

3.1.4 Building Structural Materials . . . . . . . . . . . . . . 3-2

3.2 CODES, STANDARDS AND SOURCE DOCUMENTS $\ldots \ldots \ldots \ldots$. . . .

3.3 PHYSICAL DESIGN CRITERIA $\ldots \ldots \ldots \ldots \ldots \ldots \ldots \ldots \ldots \ldots$

3.3.1 Facility Classification $\ldots \ldots \ldots \ldots \ldots \ldots \ldots \ldots \ldots \ldots$

3.3.2 Confinement Capabilities . . . . . . . . . . . . . . . 3-6

3.3.3 Safety Classification of CVDF Structure, System, and Components . . . . . . . . . . . . . . . 3-6

3.3.4 Structural Performance Categories . . . . . . . . . . . . . . 3-7

3.3.5 CVDF Building Loads . . . . . . . . . . . . . . . . 3-8

3.4 CVDF BUILDING SEISMIC ANALYSIS AND DESIGN $\ldots \ldots \ldots \ldots 3-11$

3.4 .1 General . . . . . . . . . . . . . . . . . 3-11

3.4.2 CVDF Building Structure Earthquake Loads . . . . . . . . . . 3-12

3.4 .3 Damping . . . . . . . . . . . . . . . . 3-12

3.4.4 Inelastic Energy Absorption . . . . . . . . . . . . . . . . 3-12

3.4.5 Ground Motion Components . . . . . . . . . . . . . . 3-12

3.4 .6 Analysis Procedures . . . . . . . . . . . . . . . . 3-12

3.4.7 Soil Structure Interaction (SSI) . . . . . . . . . . . . . 3-15

3.4 .8 Seismic Acceptance Criteria . . . . . . . . . . . . 3-16

3.5 SEISMIC QUALIFICATION OF EQUIPMENT $\ldots \ldots \ldots \ldots \ldots \ldots$. . . . . . .

3.5.1 In-Structure Response Spectra (ISRS) . . . . . . . . . . . 3-16

3.5.2 Stability Requirements . . . . . . . . . . . . . . . . . . . . 3-17

3.5.3 Safety Class Active Component Qualification . . . . . . . . . 3-17

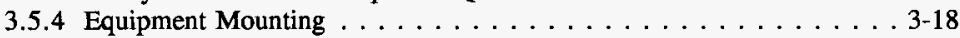

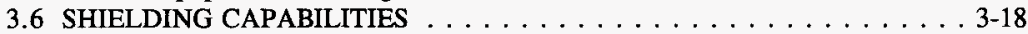

3.7 SUBSURFACE INVESTIGATION $\ldots \ldots \ldots \ldots \ldots \ldots \ldots \ldots \ldots \ldots$. $\ldots \ldots \ldots$

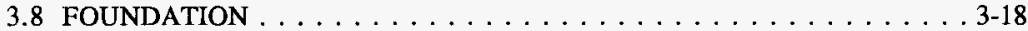

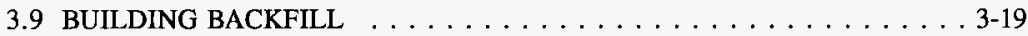


3.10 FIRE RESISTANCE $\ldots \ldots \ldots \ldots \ldots \ldots \ldots \ldots$. . . . . . . . . . . . . . . . . .

3.10 .1 Requirements . . . . . . . . . . . . . . . . . 3-19

3.10.2 Roof Decks . . . . . . . . . . . . . . . . . . . 3-19

4.0 MECHANICAL - HEATING, VENTING, AND AIR CONDITIONING . . . . . . 4-1

4.1 HEATING, VENTING, AND AIR CONDITIONING $\ldots \ldots \ldots \ldots \ldots .4$

4.1.1 General Considerations . . . . . . . . . . . . . 4-1

4.2 HVAC DESIGN CONSIDERATIONS AND STANDARD PRACTICES . . . . 4-9

4.2.1 Calculation Methods . . . . . . . . . . . . . . . 4-9

4.2.2 Ductwork and Dampers . . . . . . . . . . . . . . . 4-9

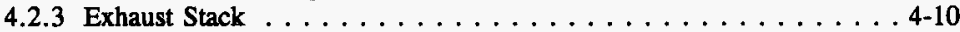

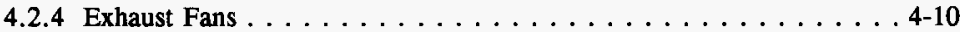

4.3 PIPED SYSTEMS $\ldots \ldots \ldots \ldots \ldots \ldots \ldots \ldots \ldots \ldots \ldots \ldots$. $\ldots \ldots$

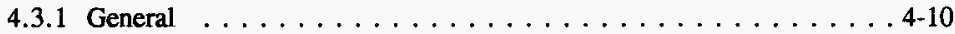

4.3.2 Water Systems . . . . . . . . . . . . . . . . . 4-11

4.3.3 Sanitary Sewage Collection $\ldots \ldots \ldots \ldots \ldots \ldots \ldots \ldots .4 .12$

4.3.4 Process Water Collection . . . . . . . . . . . . . . . . 4-12

4.3.5 Floor Drains and Firewater Collection . . . . . . . . . 4-13

4.3.6 Instrument Air System . . . . . . . . . . . . . . 4-14

4.3.7 Nitrogen System . . . . . . . . . . . . . . . . . . 4-14

4.3.8 Helium System . . . . . . . . . . . . . . . . . . . 4-14

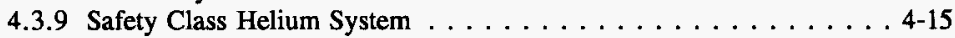

4.3.10 Vacuum System $\ldots \ldots \ldots \ldots \ldots \ldots \ldots \ldots \ldots \ldots$ 4-15

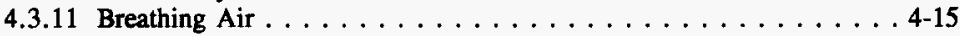

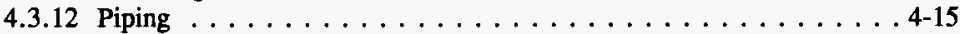

4.3.13 Safety Class Helium and Process Water Collection

System Piping Mounting And Seismic Resistance . . . . . . . 4 4-16

5.0 ELECTRICAL AND INSTRUMENTATION $\ldots \ldots \ldots \ldots \ldots \ldots \ldots \ldots$ 5-1

5.1 ELECTRICAL . . . . . . . . . . . . . . . . . .

5.2 INSTRUMENTATION $\ldots \ldots \ldots \ldots \ldots \ldots \ldots \ldots \ldots \ldots \ldots \ldots \ldots \ldots$

6.0 ARCHITECTURAL $\ldots \ldots \ldots \ldots \ldots \ldots \ldots \ldots \ldots \ldots \ldots \ldots$ 6 $\ldots \ldots \ldots$

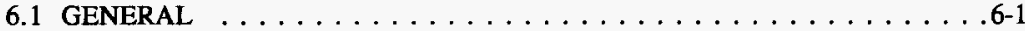

6.1 .1 Configuration . . . . . . . . . . . . . . 6-1

6.1.2 Design Criteria Documents . . . . . . . . . . . . 6-2

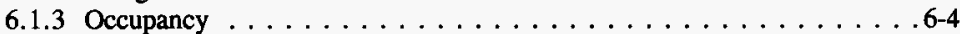

6.1 .4 Special Architecture $\ldots \ldots \ldots \ldots \ldots \ldots \ldots \ldots \ldots .6 \ldots$

6.1 .5 Handicapped Access . . . . . . . . . . . . . . . .6-5

6.1.6 Decontamination Design . . . . . . . . . . . . . . . .6-5

6.1 .7 Future Facility Use $\ldots \ldots \ldots \ldots \ldots \ldots \ldots \ldots \ldots$. . . . . . . . . . . . . . . .

6.1 .8 Egress Requirements . . . . . . . . . . . . 6-5 


\section{CONTENTS (cont)}

6.2 SPACE REQUIREMENTS $\ldots \ldots \ldots \ldots \ldots \ldots \ldots \ldots$. . . . . . . . . . . . . . .

6.2.1 Process Bay Space Requirements . . . . . . . . . . . . 6-6

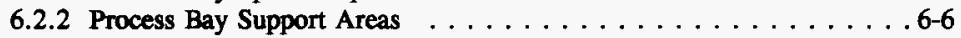

6.2.3 Personnel Decontamination Room . . . . . . . . . . . . 6-7

6.2 .4 Swipe/Count Room . . . . . . . . . . . . . . . 6-7

6.2.5 PWC Process/Handling Room . . . . . . . . . . . . . 6-7

6.2.6 Miscellaneous Materials Storage $\ldots \ldots \ldots \ldots \ldots \ldots \ldots \ldots$. . . . . . .

6.2 .7 Administrative Area . . . . . . . . . . . . . . . 6-8

6.2.8 Training/Conference Room . . . . . . . . . . . . . 6-8

6.2 .9 Quality Assurance Support $\ldots \ldots \ldots \ldots \ldots \ldots \ldots \ldots \ldots$. . . . . . . . . . . .

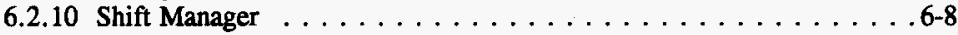

6.2.11 HPT/Radiation Monitoring $\ldots \ldots \ldots \ldots \ldots \ldots \ldots \ldots \ldots$ 6.8

6.2 .12 Control Room . . . . . . . . . . . . . . . . . . .6-9

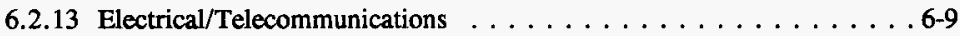

6.2 .14 Fire Riser Room . . . . . . . . . . . . . . . . . . . . 6-9

6.2.15 Men's and Women's Restrooms . . . . . . . . . . . 6-9

6.2.16 Men's and Women's Change Rooms . . . . . . . . . . . 6-9

6.3 MATERIALS AND COMPONENTS $\ldots \ldots \ldots \ldots \ldots \ldots \ldots \ldots$ 6-10

6.3.1 Doors and Windows . . . . . . . . . . . . . 6-10

6.3.2 Concrete Tilt-up Panels . . . . . . . . . . . . . . . 6-11

6.3 .3 Metals . . . . . . . . . . . . . . . . .6-11

6.3 .4 Plastic . . . . . . . . . . . . . . . 6-11

6.3.5 Moisture And Thermal Barriers . . . . . . . . . . 6-12

6.3 .6 Roofing $\ldots \ldots \ldots \ldots \ldots \ldots \ldots \ldots \ldots \ldots \ldots \ldots \ldots \ldots \ldots .12$

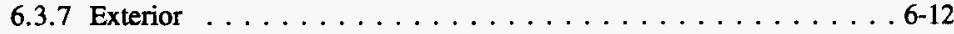

6.3.8 Joint Sealants . . . . . . . . . . . . . . 6-12

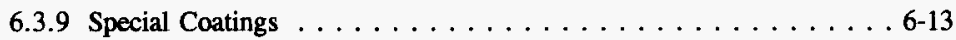

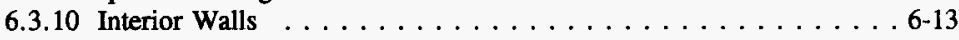

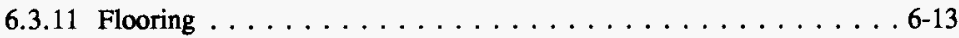

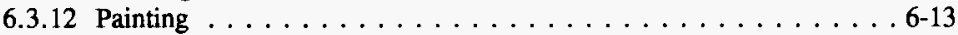

6.3 .13 Specialties . . . . . . . . . . . . . . 6 6 14

6.3 .14 Signage $\ldots \ldots \ldots \ldots \ldots \ldots \ldots \ldots \ldots \ldots \ldots \ldots .14$

6.3 .15 Conveyance System . . . . . . . . . . . . 6 6-14

7.0 PROCESS $\ldots \ldots \ldots \ldots \ldots \ldots \ldots \ldots \ldots \ldots \ldots \ldots \ldots \ldots \ldots \ldots \ldots \ldots \ldots \ldots .1$

8.0 FIRE PROTECTION $\ldots \ldots \ldots \ldots \ldots \ldots \ldots \ldots \ldots \ldots \ldots .1$

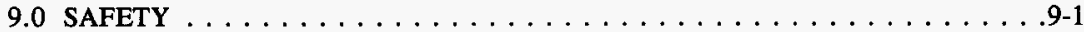

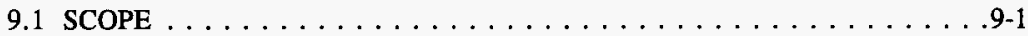

9.2 CODES AND STANDARDS $\ldots \ldots \ldots \ldots \ldots \ldots \ldots \ldots \ldots \ldots \ldots$

9.3 SAFETY DESIGN PHILOSOPHY $\ldots \ldots \ldots \ldots \ldots \ldots \ldots \ldots$. . . . 
HNF-SD-SNF-DRD-002 Rev 0

CONTENTS (cont)

9.4 SAFETY CLASSIFICATION $\ldots \ldots \ldots \ldots \ldots \ldots \ldots \ldots \ldots \ldots$ 9-2

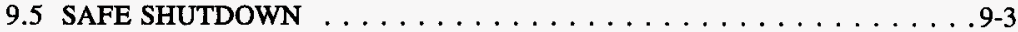

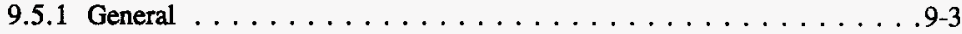

9.5.2 Safety Analysis Verification $\ldots \ldots \ldots \ldots \ldots \ldots \ldots . . .9 .3$

9.5.3 Passive Shutdown . . . . . . . . . . . . . . . 9-3

9.5.4 Safety Classification of Structures, Systems, and Components

Required to Achieve and Maintain the Safe Shutdown State . . . . 9-3

9.6 RADIOACTIVE MATERIAL CONFINEMENT . . . . . . . . . . 9-3

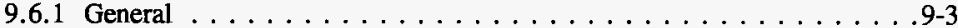

9.6.2 Primary Confinement Integrity . . . . . . . . . . . . 9-4

9.6.3 Primary Confinement Leak Management . . . . . . . . . . 9-4

9.6.4 Secondary Confinement . . . . . . . . . . . . . . . . 9-5

9.6.5 Secondary Confinement Ventilation $\ldots \ldots \ldots \ldots \ldots \ldots \ldots . .9 .5$

9.7 DESIGN BASIS ACCIDENTS $\ldots \ldots \ldots \ldots \ldots \ldots \ldots \ldots \ldots . \ldots . . \ldots . . \ldots$

9.7.1 Design Basis Fire $\ldots \ldots \ldots \ldots \ldots \ldots \ldots \ldots . \ldots \ldots$

9.7.2 Design Basis Power Failure . . . . . . . . . . . . . . . 9-6

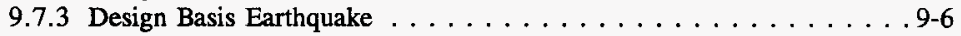

9.7.4 Design Basis Wind $\ldots \ldots \ldots \ldots \ldots \ldots \ldots \ldots . . \ldots \ldots$

9.7.5 Design Basis Tornado . . . . . . . . . . . . . . . . . .9-6

9.7.6 Design Basis Flood . . . . . . . . . . . . . . . .9-6

9.7.7 Volcanic Eruption Considerations . . . . . . . . . . . . . . 9-7

9.7.8 Design Basis Helicopter Crash . . . . . . . . . . . . 9-7

9.7.9 Design Basis MCO Flammable Gas Ignition . . . . . . . . . . 9-7

9.7.10 Other Design Basis Accidents . . . . . . . . . . . . . . . .9-7

9.8 SEISMIC CRITERIA $\ldots \ldots \ldots \ldots \ldots \ldots \ldots \ldots \ldots \ldots . . \ldots \ldots$

9.9 NUCLEAR CRITICALITY SAFETY $\ldots \ldots \ldots \ldots \ldots \ldots \ldots \ldots$. . . . . . . .

9.10 SHIELDING CRITERIA $\ldots \ldots \ldots \ldots \ldots \ldots \ldots \ldots \ldots \ldots$

9.11 ALARA CRITERIA $\ldots \ldots \ldots \ldots \ldots \ldots \ldots \ldots \ldots \ldots$

9.11.1 ALARA Definition $\ldots \ldots \ldots \ldots \ldots \ldots \ldots \ldots \ldots . . .6 \ldots$

9.11 .2 Physical Controls $\ldots \ldots \ldots \ldots \ldots \ldots \ldots \ldots \ldots . \ldots \ldots$

9.11 .3 Engineering Controls $\ldots \ldots \ldots \ldots \ldots \ldots \ldots \ldots \ldots . . \ldots \ldots$

9.11.4 Maintenance Features . . . . . . . . . . . . . . . . . .9-9

9.12 RADIOACTIVE CONTAMINATION CONTROL . . . . . . . . . . . . . . 9-9

9.12.1 Philosophy . . . . . . . . . . . . . . . . .9-9

9.12.2 Zoned Ventilation System . . . . . . . . . . . 9-10

9.12.3 Contamination Release Detection . . . . . . . . . . . 9-10

9.13 INDUSTRIAL SAFETY AND HYGIENE $\ldots \ldots \ldots \ldots \ldots \ldots \ldots . . \ldots 9-\ldots$

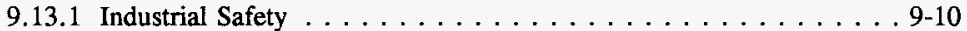

9.13.2 Industrial Hygiene $\ldots \ldots \ldots \ldots \ldots \ldots \ldots \ldots$. . . . . . . . .

9.14 INCORPORATION OF SAFETY INTO DESIGN AND OPERATION . . 9-12 


\section{HNF-SD-SNF-DRD-002 Rev 0}

\section{CONTENTS (cont)}

10.0 SYSTEMS ENGINEERING $\ldots \ldots \ldots \ldots \ldots \ldots \ldots \ldots \ldots \ldots \ldots \ldots \ldots \ldots$

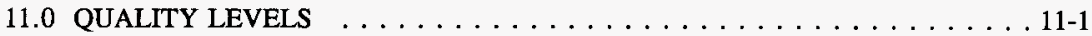

\section{LIST OF TABLES}

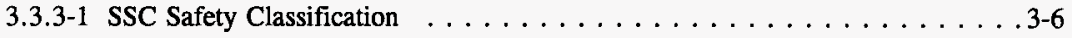

3.3.4-1 SSC Structural Performance Categorization $\ldots \ldots \ldots \ldots$. . . . . . . . . .

4.1.1.3-1 SSC Safety Classification $\ldots \ldots \ldots \ldots \ldots \ldots \ldots \ldots \ldots \ldots$ 4-3

4.1.1.3-2 SSC Structural Performance Categorization . . . . . . . . . . 4-4 
HNF-SD-SNF-DRD-002 Rev 0

\section{LIST OF TERMS}

\begin{tabular}{ll} 
ACI & American Concrete Institute \\
ACPH & Air Changes Per Hour \\
ALARA & as low as reasonably achievable \\
ANSI & American National Standards Institute \\
ASHRAE & American Society of Heating, Refrigeration, and Air Conditioning Engineers \\
CAM & continuous air monitor \\
CDR & Conceptual Design Report \\
CVDF & Cold Vacuum Drying Facility \\
CVDS & Cold Vacuum Drying System \\
DBA & design basis accident \\
DBE & Design Basis Earthquake \\
DBFL & Design Basis Flood Level \\
DOE & U.S. Department of Energy \\
DRD & design requirement document \\
FM & Factory Mutual \\
HEPA & high-efficiency particulate air \\
HP & Health Physics \\
HPT & Health Physics Technician \\
HVAC & Heating, Venting, and Air Conditioning \\
ICBO & International Conference of Building Officials \\
ISRS & in-structure response spectra \\
LBL & Lawrence Berkeley Laboratory \\
LCC & Life Cycle Cost \\
MCO & Multiple Canister Overpacks \\
NACE & National Association of Corrosion Engineers \\
NPCA & National Paint and Coating Association \\
NRC & U.S. Nuclear Regulatory Commission \\
PC3 & Performance Category 3 \\
PCI & Precast Concrete Institute \\
PCM & personnel contamination monitor \\
PHA & preliminary hazard analysis \\
PSAR & preliminary safety analysis report \\
PSE & Preliminary Safety Evaluation \\
PVC & polyvinyl chloride \\
PWC & process water collection \\
RLW & radioactive liquid waste \\
SCBA & self-contained breathing apparatus \\
SFA & Single Failure Analysis \\
SMACNA & Sheet Metal and Air Conditioning Contractors National Association \\
SNF & Spent Nuclear Fuel \\
SSC & Structure, System, and Component \\
& \\
\hline
\end{tabular}


HNF-SD-SNF-DRD-002 Rev 0

\section{LIST OF TERMS (cont)}

$\begin{array}{ll}\text { SSI } & \text { Soil Structure Interaction } \\ \text { SWP } & \text { Special Work Permit } \\ \text { TAP } & \text { toxic air pollutant } \\ \text { TLV } & \text { threshold limit value } \\ \text { UBC } & \text { Uniform Building Code } \\ \text { UL } & \text { Underwriters Laboratories } \\ \text { UMC } & \text { Uniform Mechanical Code } \\ \text { WHC } & \text { Westinghouse Hanford Company }\end{array}$


HNF-SD-SNF-DRD-002 Rev 0

This page intentionally left blank. 


\section{PROJECT W-441 COLD VACUUM DRYING FACILITY DESIGN REQUIREMENTS DOCUMENT}

\subsection{GENERAL}

\subsection{INTRODUCTION}

\subsection{REFERENCE CODES AND STANDARDS}

\subsection{GLOSSARY}


HNF-SD-SNF-DRD-002 Rev 0

This page intentionally left blank. 
HNF-SD-SNF-DRD-002 Rev 0

\subsection{SITE DEVELOPMENT}

$2-1$ 
HNF-SD-SNF-DRD-002 Rev 0

This page intentionally left blank. 


\subsection{STRUCTURAL}

This section of the Design Requirement Document (DRD) addresses the structural basis for design of the Cold Vacuum Drying Facility (CVDF). The CVDF will be a temporary facility designed to drain and dry Multiple Canister Overpacks (MCOs) filled with spent nuclear fuel (SNF) and contaminated water. It will be located in the $100 \mathrm{~K}$ area near the $\mathrm{K}$ West Basin.

\subsection{GENERAL}

\subsubsection{Structural Systems}

The CVDF consists of the following structural systems:

- The CVDF Process Building

- The CVDF Support Building

- Process equipment systems within the CVDF.

\subsubsection{CVDF Design Life Requirement}

The CVDF is to be a temporary structure. The scheduled duration for processing all the K Basins SNF is two (2) years. The design life of the facility shall be five (5) years to allow for unplanned processing duration extension.

\subsubsection{Structural Design for Demolition}

The CVDF structural design shall be selected to facilitate demolition of the facility and recycling of the structural materials, when the CVDF temporary mission is completed. All steel construction is to be preferred for this purpose except where lesser cost radiation shielding may be achieved using concrete panels attached to the steel frame. Cast-in-place concrete systems are to be avoided whenever adequate structural performance can be achieved by other means. 


\subsubsection{Building Structural Materials}

The structural systems will be constructed from one or more of the following materials unless design dictates the use of other materials or strengths.

- Reinforced Concrete:

Compressive Strength ( $f^{\prime} \partial=3,000$ psi minimum

Reinforcing Steel - ASTM A615 (fy $=60,000$ psi)

Welded Wire Fabric - ASTM A185

- Carbon Steel:

Structural Steel - ASTM A36/A36M (Fy $=36 \mathrm{ksi})$

Structural Tubing - ASTM A500 Grade B (Fy $=46 \mathrm{ksi})$

Steel Pipe - ASTM A53 Type E or S Grade B (Fy $=35 \mathrm{ksi}$ )

Welding Material - AWS D1.1, E70XX Electrode

- Bolts, Nuts, and Washers:

Common Bolts - ASTM A36 or A307

High Strength Bolts - ASTM A325

Nuts - ASTM A563

Hardened Washers - ASTM F436

Refer to ASTM Specifications for specific material requirements. For miscellaneous materials such as metal deck, grating, floor plate, crane rails, etc., see the respective project construction specification sections or detailed drawings.

\subsection{CODES, STANDARDS AND SOURCE DOCUMENTS}

\begin{tabular}{|c|c|c|c|}
\hline$\underline{\text { Document Title }}$ & Symbol/Number & & Area of Coverage \\
\hline $\begin{array}{l}\text { Performance Specification for } \\
\text { the Cold Vacuum Drying } \\
\text { Facility }\end{array}$ & $\begin{array}{l}\text { WHC-S- } 0435 \\
\text { Rev. } 0\end{array}$ & a. & $\begin{array}{l}\text { Performance } \\
\text { requirements and basic } \\
\text { design criteria }\end{array}$ \\
\hline DOE General Design Criteria & DOE Order $6430.1 \mathrm{~A}$ & a. & $\begin{array}{l}\text { General and special } \\
\text { facility design } \\
\text { requirements }\end{array}$ \\
\hline $\begin{array}{l}\text { Natural Phenomena Hazards } \\
\text { Design and Evaluation Criteria } \\
\text { for DOE Facilities }\end{array}$ & DOE-STD-1020 & a. & $\begin{array}{l}\text { Design and acceptance } \\
\text { criteria for Natural } \\
\text { Phenomena Hazards }\end{array}$ \\
\hline
\end{tabular}


Document Title

Preliminary Safety Evaluation

for the Spent Nuclear Fuel

Project's Cold Vacuum Drying

Facility

Seismic Design for Buildings

Seismic Design Guidelines for

Essential Buildings

Minimum Design Loads for

Buildings and Structures

Seismic Analysis of Safety-

Related Nuclear Structures and

Commentary

Specification for the Design, Fabrication, and Erection of Steel Safety-Related Structures for Nuclear Facilities

Uniform Building Code
Symbol/Number

WHC-SD-SNF-PSE-003

Rev. 0

TM 5-809-10

TM 5-809-10-1

ASCE 7

ASCE 4

ANSI/AISC N690

UBC

AISC - M016

AISC Manual of Steel

Construction, Ninth Edition

ACI Building Codes and Guidelines
ACI-349

ACI-318

\section{Area of Coverage}

a. Establishes hazard categorization

a. Seismic design criteria and guidance

a. Seismic design criteria and guidance for essential or high-risk buildings

a. Material loads and minimum dead, live, snow, and wind loads

a. Acceptable methods for the seismic analysis of Safety Class SSCs

a. Safety Class Steel Structure Design

a. Defines loading including seismic and design criteria for PC-2 structures

b. Masonry design

c. Timber design

d. Fire-resistive standards

a. Structural steel design

b. Plastic structural steel design

a. PC-3 reinforced concrete structure design

b. PC-2 significant concrete structure design 
Document Title

ACI Building Codes and Guidelines (cont)

Structural Welding Code

AISI Specification for the Design of Cold Formed Steel Structural Members 1986 Edition

Stainless Steel - Cold Formed

Structural Design Manual - 1974

Edition

DOE Natural Phenomena

Hazards Mitigation

Spent Nuclear Fuel Path

Forward, Additional NRC

Requirements
Symbol/Number

ACI-318 (Chapter 21)

ACI-207.1R

ACI-207.2R

ACI-224

ACI-350

AWS D1.1

AISI

AISI

DOE Order 5480.28

WHC-SD-SNF-DB-003

Rev. 2

WHC-SD-SNF-DB-004

Spent Nuclear Fuel Project, Rev. 1

Seismic Design Criteria, Rev. 1

Design Loads for Facilities
GC-LOAD-01

\section{Area of Coverage}

c. For ductile design and detailing requirements for elements resisting seismic loads in regions of moderate seismic risk (Safety Class)

d. Massive concrete

e. Control of cracking

f. Concrete sanitary structures

a. Structural welding

a. Light gauge cold formed steel design

b. Cold formed stainless steel design

a. DOE policy and requirements for natural phenomena hazard mitigation

a. Design provisions required to provide NRC equivalency as interpreted by WHC letter 962883 dated July 2, 1996

a. NRC seismic equivalency evaluation

a. General structural design criteria 
Document Title

Cold Vacuum Drying System Natural Phenomena Hazards
Symbol/Number

WHC-SD-SNF-DB-010

Rev. 1

\section{Area of Coverage}

a. Project specific earthquake

design data

b.

Project specific wind, pressure, and missile

c. data

Project specific volcanic

d. ash data

Project specific river flooding and local run-off flooding

e. criteria

Snow load criteria

WHC-SD-W236A-TI-

002, Rev. 1

WHC-SD-GN-DGS-

30006, Rev. 1a

SAND92-0140.Uc-523

(Sandia National

Laboratory)

Seismic Qualification

Utility Group

Procedure (GIP) for Seismic

Verification of Nuclear Power

Plant Equipment, Revision 2

IEEE Recommended Practice for

ANSI/IEEE 344

Seismic Qualification of Class

1E Equipment for Nuclear

Power Generating Station

Preliminary Assessment:

Tornado Missile Hazards to Cold

Vacuum Drying System and Hot

Conditioning System
SAIC July, 1996 a. Soils property data

a. Equipment anchorage requirements seismic qualification of equipment

a. Experience data for seismic qualification of equipment

b. Testing requirements for equipment qualification

a. Probabilistically eliminates tornado missile consideration a. Experience data for 


\subsection{PHYSICAL DESIGN CRITERIA}

\subsubsection{Facility Classification}

The CVDF Process Building is classified as a Nonreactor Nuclear Facility per DOE Order 6430.1A, Section 1300. A Preliminary Hazards Assessment (RIPI-96-001 April, 1996) has determined that the CVDF will be a Hazard Category 2 nuclear facility per the guidelines of DOE STD 1027. The office area shall be a non-nuclear facility rated for general use per Uniform Building Code (UBC).

\subsubsection{Confinement Capabilities}

The CVDF shall be constructed so that it has two confinement structures. Primary confinement shall be accomplished by the MCO and the drying system piping that will be connected to it. The primary confinement shall prevent release of radioactive material into the interior of the CVDF process bays under normal operational and upset conditions. Secondary confinement shall be accomplished with the partitions that define each process bay. The secondary confinement shall block release of radioactive material into the environment outside the facility in the event that the primary confinement fails. The structures that shall be considered to be part of the secondary confinement are the walls, floors, and roof that define each of the process bays, the ventilation system exhaust highefficiency particulate air (HEPA) filters and the ductwork section leading from the HEPA filter housing through the confinement wall, the isolation damper and inlet ductwork through the confinement wall, and the structures that hold these key ventilation system structures.

\subsubsection{Safety Classification of CVDF Structure, System, and Components}

The safety classification criteria for CVDF structures, systems, and components (SSCs) is given in Chapter 9 of this Design Basis Document. The application of the criteria to the CVDF SSCs yields the following classification:

Table 3.3.3-1. SSC Safety Classification. (2 sheets)

\begin{tabular}{|l|l|}
\hline \multicolumn{1}{|c|}{ SSC Name } & Safety Classification \\
\hline MCO* & Safety Class \\
\hline Process Hood, Duct to the HEPA Filter, Exhaust HEPA Filter & Safety Significant \\
\hline Supply Air Backdraft Dampers and Exhaust Isolation Dampers & Safety Significant \\
\hline Process Equipment Skid & Safety Significant \\
\hline Process Building Structure & Safety Significant \\
\hline
\end{tabular}


Table 3.3.3-1. SSC Safety Classification. (2 sheets)

\begin{tabular}{|l|l|}
\hline \multicolumn{1}{|c|}{ SSC Name } & \multicolumn{1}{c|}{ Safety Classification } \\
\hline Safety Class Helium Purge System & Safety Class \\
\hline Stack & Safety Significant \\
\hline PWC Skid & Safety Significant \\
\hline
\end{tabular}

*Not provided by the CVDF.

\subsubsection{Structural Performance Categories}

The structural performance categorization as defined by DOE STD 1021 for the SSCs given in Table 3.3.3-1, as well as for items that have the potential for failure leading to damage of a safety class item are:

Table 3.3.4-1. SSC Structural Performance Categorization.

\begin{tabular}{|l|c|c|}
\hline \multicolumn{1}{|c|}{ SSC Name } & $\begin{array}{c}\text { SSC } \\
\text { Performance }\end{array}$ & $\begin{array}{c}\text { Anchorage } \\
\text { Performance }\end{array}$ \\
\hline MCO* & & \\
\hline Duct to the HEPA Filter, Exhaust HEPA Filter & PC2 & PC3 \\
\hline $\begin{array}{l}\text { Supply Air Backdraft Dampers and Exhaust } \\
\text { Isolation Dampers }\end{array}$ & PC2 & PC2 \\
\hline Process Equipment Skid & PC3 & PC3 \\
\hline Process Building Structures & PC3 & PC3 \\
\hline Safety Class Helium Purge System & PC3 & PC3 \\
\hline Stack & PC3 & PC3 \\
\hline Bay Crane and Bridge & PC2 & PC3 \\
\hline PWC Skid & PC2 & PC2 \\
\hline PWC Storage Tank & PC2 & PC2 \\
\hline Administrative Area & PC2 & PC2 \\
\hline Process Hood & PC3 & PC3 \\
\hline
\end{tabular}

*Not provided by the CVDF. 
Safety Class SSCs provided by the CVDF shall be subjected to PC3 criteria. Safety significant SSCs whose failure could damage a safety class item shall be subjected to PC3 criteria. Safety significant SSCs whose failure can exceed the on-site dose consequence limitation shall be subjected to PC3 criteria.

\subsubsection{CVDF Building Loads}

\subsubsection{Normal Loads.}

Dead Loads. Dead (D) loads include the gravity load of structures, permanent equipment, piping, static liquid, soil, long-term stored materials, permanent partitions and any other permanent static load. Dead load criteria for the CVDF are given in GC-LOAD-01.

Live Loads. Live (L) loads are the loads superimposed on structures or components due to the use and occupancy of the facility. Live loads, in general, include the weight of movable objects such as personnel, temporarily stored materials, movable partitions, maintenance equipment, forklifts, hoists and cranes. Live load criteria for the CVDF are given in GC-LOAD-01.

Snow Load. Snow load (S) criteria as specified in "Cold Vacuum Drying System Natural Phenomena Hazards" (WHC-SD-SNF-DB-010) shall be the criteria given in ASCE-7 $\left(20 \mathrm{lb} / \mathrm{ft}^{2}\right)$ Chapter 8 .

Thermal Loads (T) and Creep/Shrinkage (C). Self-straining forces and effects arise from restraint of expansion or contraction due to temperature change, shrinkage, creep or differential settlement. These forces will be considered in the facility design. All structures and items exposed to exterior environment will be designed for maximum daily temperature of $120^{\circ} \mathrm{F}$ and a minimum daily temperature $-20^{\circ} \mathrm{F}$ (WHC-S-0435, Section 4.4). The effects of thermal gradients due to the difference between the internal and external temperatures in massive concrete members or structures will be taken into account in accordance with Appendix A of ACI 349.

The minimum linear coefficient of shrinkage will be assumed to be 0.0002 in./in. per DOE Order 6430.1A.

3.3.5.2 Severe and Extreme Environmental Loads. The design basis natural phenomena loads and conditions that are to be applied to the CVDF structural design are tabulated in "Cold Vacuum Drying System Natural Phenomena Hazards" (WHC-SD-SNF-DB-010) Table 1.

Wind and Tornado. Straight wind load (W) and missile load criteria are given in WHC-SD-SNF-DB-010 Chapter 3. 
Tornado wind speed (W) and pressure drop loads for the CVDF are given in "Cold Vacuum Drying System Natural Phenomena Hazards" (WHC-SD-SNF-DB-010) Chapter 3.

Earthquake Loads. Design Basis Earthquake loads and spectra are given in "Cold Vacuum Drying System Natural Phenomena Hazards" (WHC-SD-SNF-DB-010) Section 2.2.

Ashfall Loads. The design requirements for ashfall are given in "Cold Vacuum Drying System Natural Phenomena Hazards" (WHC-SD-SNF-DB-010) Section 2.2. The CVDF does not have PC4 SSCs or safety components that must be active after a design basis ashfall.

Flood Loads. The design basis river flood level assuming a 25\% Grand Coolee dam breach is $460 \mathrm{ft}$. This is $16 \mathrm{ft}$ below the CVDF elevation ("Cold Vacuum Drying System Natural Phenomena Hazards" [WHC-SD-SNF-DB-010] Chapter 5). No action is required.

The design basis local run-off requirements are given in "Cold Vacuum Drying System Natural Phenomena Hazards" (WHC-SD-SNF-DB-010) Section 5.2.1.

Earth and Groundwater Loads. Earth and groundwater load requirements are given in GC-LOAD-01 (paragraph 6.5). Dynamic earth pressures shall be considered in the design of PC3 below grade structures.

\subsubsection{Load Factors and Load Combinations.}

3.3.5.3.1 Load Combinations and Stress Limits. The CVDF building shall be designed to adequately resist the effects of various load combinations. The governing documents in determining load combinations for PC3 structures are as follows:

Dead load, live load and accident load combinations:

- ACI 349-90 for reinforced concrete

- AISC/ANSI N690 for structural steel.

Seismic and wind load combinations:

- DOE-STD-1020-94 for both reinforced concrete and structural steel.

- ACI 349-90 for reinforced concrete.

- AISC/ANSI N690 for structural steel. 
3.3.5.3.2 Reinforced Concrete Design. The following load combinations shall be used to determine the demand, De on reinforced concrete members of the CVDF building:

\section{Load Combination.}

1. $\mathrm{D}_{\mathrm{c}}=1.4 \mathrm{D}+1.7 \mathrm{~L}+1.7 \mathrm{H}$

2. $\mathrm{D}_{\mathrm{s}}=\mathrm{D}+\mathrm{L}+\mathrm{H} \pm \mathrm{T} \pm \mathrm{E}$

3. $\mathrm{D}_{\mathrm{c}}=0.9[\mathrm{D}+\mathrm{L}+\mathrm{H}+\mathrm{T}+\mathrm{W}]$

4. $\mathrm{D}_{\mathrm{e}}=\mathrm{D}+\mathrm{L}+\mathrm{H} \pm \mathrm{E}$

5. $\mathrm{D}_{\mathrm{c}}=\mathrm{D}+1.3 \mathrm{~W}$

6. $\mathrm{D}_{\mathrm{c}}=1.05 \mathrm{D}+1.3 \mathrm{~L}+1.3 \mathrm{H}+1.05 \mathrm{~T}$

7. $\mathrm{D}_{\mathrm{e}}=1.4 \mathrm{D}+1.7 \mathrm{~L}+1.7 \mathrm{H}+1.7 \mathrm{~W}$

8. $\mathrm{D}_{\mathrm{e}}=1.05 \mathrm{D}+1.3 \mathrm{~L}+1.3 \mathrm{H}+1.3 \mathrm{~W}$

Where any load reduces the effects of other loads, the load factor for that load shall be taken as zero, unless that load can be demonstrated as always present and in such a case, the load factor shall be taken as 0.9 .

Where

$$
\begin{aligned}
& \mathrm{D}=\begin{array}{l}
\text { Dead load including collateral dead load where it produces the more critical } \\
\text { condition }
\end{array} \\
& \mathrm{L}=\text { Live load, including applicable crane impact loads, snow load } \\
& \mathrm{T}=\text { Normal operational thermal load } \\
& \mathrm{W}=\text { Wind load } \\
& \mathrm{W}_{\mathrm{t}}=\text { Wind load due to tornado } \\
& \mathrm{E}=\text { Earthquake load } \\
& \mathrm{H}=\text { Earth pressure load. }
\end{aligned}
$$

3.3.5.3.3 Structural Steel Design. The following load combinations shall be used to determine the demand, De on structural steel members of the CVDF building:

\section{Load Combination}

1. $\mathrm{D}_{\mathrm{e}}=$

2. $\mathrm{D}_{\mathrm{e}}=$

3. $\mathrm{D}_{\mathrm{c}}=$

4. $\mathrm{D}_{\mathrm{e}}=$

5. $\mathrm{D}_{\mathrm{c}}=$

$\mathrm{D}+\mathrm{L}+\mathrm{L}_{\mathrm{T}}+\mathrm{T}$

$\mathrm{D}+\mathrm{L}+\mathrm{L}_{\mathrm{T}}+\mathrm{T} \pm \mathrm{E}$

$\mathrm{D}+\mathrm{L}+\mathrm{L}_{\mathrm{T}}+\mathrm{T} \pm \mathrm{W}$

$\mathrm{D}+\mathrm{L}+\mathrm{L}_{\mathrm{T}}$

$\mathrm{D}+\mathrm{L}+\mathrm{L}_{\mathrm{T}} \pm \mathrm{E}$ $\underline{\text { Stress Limit Coefficient }}{ }^{\mathrm{d}}$

$1.0^{4}$

$1.6^{\mathrm{b}}$

$1.5^{\circ}$

$1.6^{\mathrm{b}}$

$1.7^{\mathrm{b}}$ 

6. $\mathrm{D}_{\mathrm{e}}=\mathrm{D}+\mathrm{L}+\mathrm{W}$
7. $\mathrm{D}_{\mathrm{e}}=\mathrm{D}+\mathrm{L}+0.5 \mathrm{~L}+\mathrm{W}$
8. $\mathrm{D}_{\mathrm{e}}=\mathrm{D}+\mathrm{L}+\mathrm{L}_{\mathrm{s}}+0.5 \mathrm{~W}$
9. $\mathrm{D}_{\mathrm{c}}=0.85 \mathrm{D}+\mathrm{W}$
10. $\mathrm{D}_{\mathrm{e}}=\mathrm{D}+\mathrm{L}+\mathrm{L}_{\mathrm{T}}+\mathrm{W}_{\mathrm{t}}$

Where all symbols have the same meanings as above except soil pressure, $\mathrm{H}$, shall be combined with live load in the combinations above and:

L = Live loads, including applicable crane impact loads, but excluding snow or roof live loads

$\mathrm{L}_{\mathrm{T}}=$ Larger of roof live load or snow load

All load combinations shall be checked for the no live load condition.

(a) For primary plus secondary stress, the allowable limits are increased by a factor of 1.5 .

(b) The stress limit coefficient in shear shall not exceed 1.4 in members and bolts.

(c) Secondary stresses which are used to limit primary stresses shall be treated as primary stresses. In no instance shall the allowable stress exceed $0.70 \mathrm{~F}_{\mathrm{u}}$ (In axial tension $0.7 \mathrm{~F}_{\mathrm{u}}$ times the ratio $\mathrm{Z} / \mathrm{S}$ for tension plus bending). $\mathrm{F}_{\mathrm{u}}$ Is the specified minimum tensile strength of the material; $Z$ is the plastic section modulus; and $\mathrm{S}$ is the elastic section modulus.

(d) Stress limit coefficients are applied to primary stress limits given in Sections Q1.5.1, Q1.5.2, Q1.5.3, Q1.5.4, Q1.5.5, Q1.6, Q1.1.0 and Q1.11 of AISC/ANSI N690.

\subsection{CVDF BUILDING SEISMIC ANALYSIS AND DESIGN}

\subsubsection{General}

This section provides seismic analysis and design criteria for CVDF building SSCs.

The criteria include input definition, response determination approach, performance requirements and seismic design considerations. These criteria are based primarily on the guidelines provided by DOE-STD-1020, TM 5-809-10-1, and UBC. 


\subsubsection{CVDF Building Structure Earthquake Loads}

Performance categories per DOE STD-1020 are defined for the safety SSCs in Section 3.3.4. PC3 Design Basis Earthquake loads for the performance categories are defined in Section 3.3.5.2. There is no Operating Basis Earthquake for the CVDF.

PC2 earthquake loads shall be those given by UBC for Seismic Zone 2B, for essential facilities (DOE-STD-1020)

The CVDF will be designed for passive safety. Achievement or maintenance of the safe shutdown condition will not require action by active components. No small-magnitudenear-field earthquake analysis need be performed.

\subsubsection{Damping}

For purposes of elastic dynamic analysis taking into account spectral damping values, the damping coefficients given in DOE STD 1020-94 Table 2.3 shall be used. The Response Level 3 damping values shall be used as directed by DOE STD 1020-94 Section C 4.4.1.

\subsubsection{Inelastic Energy Absorption}

Inelastic absorption factor values, $F_{u}$, are to be taken from DOE STD 1020 Table 2-4. The maximum spectral acceleration shall be used for fundamental frequencies greater than the frequency at which the peak spectral acceleration occurs when $F_{u}>1.0$.

\subsubsection{Ground Motion Components}

Three ground acceleration components shall be considered (two horizontal and one vertical). Combination of direction components shall comply with ASCE 4.

\subsubsection{Analysis Procedures}

PC3 SSCs shall be subjected to a dynamic analysis. Dynamic analysis of the CVDF building structure shall be an elastic response spectrum analysis using a commercially available finite element code.

The extent and detail of structural models will be consistent with obtaining realistic structural response of items to be analyzed within an engineering degree of accuracy. 
Modeling of items will be conducted to the detail required to ensure obtaining the actual response and will be consistent with the method of analysis being used. For dynamic analysis, the model will be, as a minimum, a lumped-mass system interconnected by elastic elements.

The models must adequately represent the physical characteristics of structures, systems, and components and their corresponding response to seismic excitations. Where it is difficult to model various structures, systems, and components, parametric studies are required to determine sensitivity of the model to various parameter changes; e.g., mass, stiffness, material properties, etc. Refining the model is then done to reflect the appropriate parameter representation as determined by the studies.

All physically connected structures, systems, and components will be represented as a combined single mathematical model unless such connected structures, systems, and components are permitted to be uncoupled by the following considerations. All physically connected structures, systems, and components are coupled to some degree and should be modeled accordingly. However, for purposes of simplicity and economy, in many cases it is desirable and sufficiently accurate to separate models of structural systems into two or more individual parts. Models of structural systems may be uncoupled according to the following general guidelines.

There are two distinct types of coupling conditions:

1. Where structures, systems, or components are coupled together but supported independently, the coupled point may be considered as additional support point.

2. Where the structures, systems, or components are physically coupled and physically support one or another through the coupling point, one being the primary support. conditions.

All other coupling conditions are combinations of these two types of sampling

Basically, uncoupling can be justified where the model of each subsystem or subcomponents is developed to account for interaction effects at interfaces, or where it is shown that the dynamic response of subsystems and subcomponents is independent as modeled.

The response spectrum technique requires modal analysis of the structure to determine its natural frequencies and the corresponding mode shapes. The dynamic characteristics of the structure are used in the calculation of structural response such as displacements, forces and moments, and stresses due to externally applied seismic forces as defined by the amplified response spectra. The modal analysis will include all significant modes of the 
structure with frequencies below the cut-off frequency. In addition, the analyst is required to demonstrate that the analysis accounts for the inertial effects of modes above the cut-off frequency.

When uncoupling is justified, the subdivided structures, systems, and components will be modeled in a consistent manner. When structures, systems, and components are subdivided and, as a result, become supported structures, care must be taken in providing the input motion that is representative of the seismic response of the supporting structure.

For efficient modeling, geometric, mass and reflective symmetry may be utilized to reduce the number of degrees-of-freedom; however, care must be taken to ensure that significant translational and rotational degrees-of-freedom are considered at mass points. In addition, consideration must be given to the coupling effects which may occur between the translational and rotational degrees-of-freedom where the center of mass and center of resistance (for either torsional and bending effects) do not coincide.

Analytic techniques will account for the effect of horizontal torsional moments due to actual and accidental eccentricities between centers of mass and rigidity at each level.

Inclusion of accidental torsion accounts for such factors as spatial variations of horizontal input motions applied to long buildings, rotational components of ground motions, the effects of nonstructural elements or building stiffness and inertial characteristics, the actual distribution of dead and live loads, uncertainties in defining the building's material properties for dynamic analysis, and variations in foundation -soil coupling effectiveness.

In addition to the horizontal torsion induced by the eccentricity of the calculated center of mass from the calculated center of rigidity, an additional torsion resulting from an accidental eccentricity will be considered in accordance with Section 3.3.1.2 of ASCE 4-86. The required accidental eccentricity is equal to $5 \%$ of the building dimension measured perpendicular to the direction of the lateral force. The accidental torsion takes into account several factors including the possibility of non-vertical propagation of seismic waves.

Where torsional irregularity exists as specified in the UBC, the effects will be accounted for by increasing the accidental torsion by an amplification factor.

Torsional moments are to be resisted by the structure's lateral force-resisting system and the resulting torsional member shear forces added to direct shear forces by standard analytical methods.

At foundations or points of support, the rocking degrees-of-freedom should be considered in the mathematical model. Although, in some cases, such degrees-of-freedom are insignificant, care should be utilized to justify their elimination.

Discontinuities that may exist in a structure, system, or component (e.g., drastic changes in stiffness, gaps, or clearances) that become part of the mathematical model may 
require special consideration. It may be necessary to treat gap or clearance discontinuities as nonlinearities, and such discontinuities may be subject to impact forces. An appropriate mathematical procedure for representing the response of such gaps or clearances will be used in determining the impact forces for design purposes. In addition, at points of rapid changes in stiffness, attention should be focused on stress risers.

When modeling equipment, the mathematical model should represent the equipment in its operational mode if it must remain in operation to maintain its required function.

The following special considerations are applicable to items supported by other structures rather than being directly supported on ground.

Where a supported item has two or more response frequencies that exist within the broadened resonant frequency band of the supporting point response spectrum, the spectrum may be modified in the analysis to prevent unnecessary conservatism. Since the supporting structure, system, or component can have only one resonant frequency, the broadened spectrum is modified such that its peak corresponds to one of the supported substructure, subsystem, or subcomponents frequencies within the broadened range as described RDT F 9-2. The supported substructure, subsystem, or subcomponents is analyzed using the supporting spectrum modified as shown once for each frequency in the broadened band. For example, if three frequencies of the supported substructure, subsystem, or subcomponents were in the broadened band, there would be three analyses, and the analysis producing the largest total response would be used for the design.

For the condition where a substructure, subsystem, or subcomponents is supported by more than one supporting structure, system, or component, there will be differing response spectra at various support points. These support point spectra will be superimposed on each other, and the design spectrum for the substructure, subsystem, or subcomponents taken as the upper bound envelope of the support point spectra considered.

PC2 structures shall be structurally designed and analyzed in accordance with the static equivalent procedure given in UBC for Seismic Zone $2 B$, essential facilities.

\subsubsection{Soil Structure Interaction (SSI)}

A fixed base seismic analysis shall be performed because the building foundation is shallow. Soil structure interaction shall be accounted for by peak broadening in the high frequency range. This is consistent with the criteria given in DOE STD 1020 where it is stated that it is permissible to ignore the beneficial effects of SSI and assume that the design basis earthquake ground motion applies to the foundation level of the structure provided that any frequency shifting due to SSI is considered. A fixed base analysis neglects the benefits of foundation scattering and radiation damping. The effects of rocking modes are excluded in this approach but are small for short buildings such as the CVDF. 
Verification that the peak broadening approach for accounting adequately for SSI is appropriate shall be achieved by extending soil properties data given in Probabilistic Seismic Hazard Analysis, DOE Hanford Site, Washington, WHC-SD-W236A-TI-002, Rev. 1.

\subsubsection{Seismic Acceptance Criteria}

The resulting seismic forces for each element are reduced by the inelastic demand-capacity ratio $(\mathrm{Fu})$ to obtain the inelastic seismic demand which is then combined with other loads in accordance with Section 3.3.5.3 to determine the total demand for the element. The capacities of the elements are obtained from code allowable ultimate or yield values. Once the capacity of an element is computed it is compared to the total demand for that element.

For steel, the capacity is taken to be the stress limit coefficient times the ANSI N690 elastic capacity for Allowable Stress Design or can be taken to be the plastic capacity per AISC (M016) Chapter N. For concrete the American Concrete Institute (ACI) ultimate strength capacities will be used. Note that strength reduction factors, $\mathrm{f}$, are retained.

Inherent to the acceptability of this procedure is the ability to develop ductility levels comparable to that achieved through the use of the UBC's design and detailing requirements.

\subsection{SEISMIC QUALIFICATION OF EQUIPMENT}

\subsubsection{In-Structure Response Spectra (ISRS)}

Design in-structure response spectra (ISRS) are required as input for structure-supported PC3 items such as substructures, equipment, or piping (DOE STD 1020). Such ISRS will be developed by one of two methods: time-history or Modified Singh. Requirements for the methods are described below.

Raw ISRS developed for locations will be smoothed and peaks broadened according to procedures described in Regulatory Guide 1.122 .

In order to limit the number of ISRS required for design or qualification of supported items, it is appropriate to envelop spectra generated from various response point locations to create design ISRS.

When generating ISRS, care must be taken to include response contribution from all input directions. Combination of components will be in accordance with Section 3.4.5.

Time history generation is essentially a modal time-history response analysis with appropriate models to accurately develop time-history response at key support point 
locations. The support motions are then to be used for generation of raw spectra which are then enveloped, smoothed, and broadened to provide ISRS suitable for design purposes. The generation of raw spectra will utilize an acceptable response spectrum generation method similar to that used for generation of ground spectra. ISRS generation and development will meet the general requirements of the Regulatory Guide 1.122.

In the Modified Singh method, ISRS are generated directly from design spectra which provide input criteria for supporting structures. Required enveloping, smoothing and broadening must conform to criteria of the Regulatory Guide 1.122.

When utilizing the Modified Singh Approach, one spectra at each level will be calculated utilizing both time history and the Modified Singh Methods. Comparison of the raw spectra will be made to provide assurance that all aspects of the Singh analysis have been properly carried out.

A method for approximating a design floor response spectrum is presented in Chapter 6 of TM 5-809-10-1.

\subsubsection{Stability Requirements}

All items will be designed to resist the overturning and sliding effects caused by earthquake loads. Items will be positively anchored to supporting structures or foundations.

At the interface of major structure foundations with soil, stability ratio for overturning and sliding will be 1.0 for Design Basis Earthquake (DBE) loads. The stability ratio for overturning is the ratio of the dead load resisting moment and the earthquake induced overturning moment. The sliding stability ratio is the ratio of applicable resisting forces (e.g., fractional and passive earth loads) and the maximum horizontal earthquake forces applied to the structure in a given direction at the foundation soil interface.

\subsubsection{Safety Class Active Component Qualification}

The CVDF design method is to achieve and maintain safe shutdown without the use of active components. However, the supply air isolation dampers, the exhaust isolation dampers, and the components in the Safety Class Helium Purge System must change to their fail safe positions and must perform their passive functions. These items shall be qualified following the PC3 qualification guidelines given in DOE STD 1020 Section 2.4-1 either by laboratory testing in accordance with IEEE-344 or by acceptance of data drawn from an approved earthquake experience database (SAND92-0140.UC-523, "Generic Implementation Procedure (GIP) for Seismic Verification of Nuclear Plant Equipment," Seismic Qualification Utility Group, 1991). 


\subsubsection{Equipment Mounting}

Equipment anchorage requirements shall be as defined in DOE STD 1020 Section 2.4.1 and in WHC-SD-GN-DGS-30006.

Equipment supports will be designed to avoid resonance resulting from the harmony between the natural frequency of the structure and the operating frequency of reciprocating or rotating equipment supported on the structure.

The operating frequency of supported equipment will be determined from manufacturer's data prior to completion of structural design.

Where economically practical, resonance will be prevented by designing equipment isolation supports to reduce the dynamic transmission of the applied loads. Isolation supports shall be designed for seismic events.

Anchor bolts and expansion anchors for Safety Class and Safety Significant items will be designed in accordance with the guidelines contained in WHC-SD-GN-DGS-30006, Section 4.0 and Appendix A.

Anchor bolts and expansion anchors for non-safety class and non-safety significant items will conform to UBC requirements and industry standards with allowable loads and installation as approved by the International Conference of Building Officials (ICBO) Evaluation Reports.

\subsection{SHIELDING CAPABILITIES}

Should concrete be used for radiation shielding, the design shall comply with ACI 349 .

\subsection{SUBSURFACE INVESTIGATION}

A subsurface investigation shall be performed as required for critical facilities (including radioactive material handling facilities) by DOE Order 6430.1A Section 201-1. The data shall be used to verify conservative assumptions made in the foundation design and in analyzing SSI effects in the seismic analysis.

\subsection{FOUNDATION}

The foundation shall be designed to support the structure and keep differential settlements within acceptable limits. Frost depth is a maximum of 30 in. below grade. Allowable basic soil bearing pressure shall be 1500 psf and can be modified by footing depth/width to a maximum of $4500 \mathrm{psf}$ per UBC. 


\subsection{BUILDING BACKFILL}

Backfill around building foundations, under slabs, etc., shall be compacted to a minimum of $95 \%$ of maximum density (depending upon type of structure and load requirements) at optimum moisture content levels. Soil shall be compacted in layers not exceeding 8 in. in thickness. Hanford standard construction specification section 02200 and 02700 shall be utilized.

\subsection{FIRE RESISTANCE}

\subsubsection{Requirements}

Fire resistance requirements and types of construction shall be in accordance with the UBC criteria for fire resistant materials used in the design and construction of fire resistive designs as listed in the Underwriters Laboratories (UL) Fire Resistance Directory. Fire resistance ratings will be based on UBC criteria and the improved risk criteria defined by DOE Order 6430.1A and DOE Order 5480.7. This includes the separation of adjacent non-compatible groups by two-hour fire barriers.

\subsubsection{Roof Decks}

Metal roof decks shall be constructed, for fire protection purposes, as Class I with these restrictions:

- Insulation shall be of fiberboard, fiberglass, or foam glass materials.

- The vapor barrier material shall be noncombustible.

- Factory Mutual (FM) Data Sheet 1-28S and the FM Approval Guide shall be used for acceptable materials selection and construction practices. 
HNF-SD-SNF-DRD-002 Rev 0

This page intentionally left blank. 


\subsection{MECHANICAL - HEATING, VENTING, AND AIR CONDITIONING}

\subsection{HEATING, VENTING, AND AIR CONDITIONING}

\subsubsection{General Considerations}

4.1.1.1 Functional Requirements. Ventilation requirements will comply with DOE Order 6430.1A, Sections 0110-12.4, 1161-4, 1300-7 and 1550. System design shall also comply with the applicable guidelines of American Society of Heating, Refrigeration, and Air Conditioning Engineers (ASHRAE). The basic functional requirements for the Heating, Venting, and Air Conditioning (HVAC) systems shall be as follows:

- Maintain office and operational areas at temperatures recommended by the appropriate codes and standards to assure personnel comfort and safety and to protect equipment during normal and off-normal conditions.

- Detect and monitor ventilation flows and pressure differentials throughout the facility as required to prevent the possible spread of hazards such as radioactive contamination. All confinement ventilation air flows and pressure differentials shall be alarmed if out of compliance.

- Ensure facility air flows are from areas of less contamination potential to areas of greater contamination potential. Means shall be provided to seal all confinement boundaries in the event of loss of ventilation and/or pressure differentials except for penetrations which are provided with high-efficiency particulate air (HEPA) filters. Radioactive materials shall be confined as close as practicable to the point of release. Provide an interlocked HVAC control system so that reversed air flow patterns cannot be established.

- Maintain as low as reasonably achievable (ALARA) release of radioactivity to the environment as required by DOE Order 5400.5 and DOE Order 6430.1A Section 1300-1.4. The exhaust ventilation system shall be sized to ensure radiological doses are maintained at ALARA levels in the event of the largest credible breach.

- Satisfy Single Failure Analysis (SFA) criteria for all safety class or safety significant systems and/or components serving confinement areas as required to maintain contamination control based on the results of the preliminary safety analysis report (PSAR).

- Provide deliverable air quantities to all areas sufficient to remove heat, hazardous and radioactive particulate matter and gases, and other contaminants. The system shall provide proper distribution of air flow throughout the facility during normal and off-normal and maintenance activities. Ventilation system shall meet all 
deliverable air quantity requirements of ASHRAE Standard 62 and any other specific equipment requirements discussed in DOE Order 6430.1A

Sections $1550-2.5$ and $1550-99.0$.

- Provide a minimum deliverable air quantity of 6 Air Changes Per Hour (ACPH) for all ventilation and exhaust air systems serving the confinement areas.

4.1.1.2 Contamination Confinement. The radioactive material within the Cold Vacuum Drying Facility (CVDF) is isolated from the environment by two levels of confinement. The primary confinement is achieved by the Multiple Canister Overpack (MCO), process piping, radioactive liquid waste (RLW) drain lines, RLW tanks, and so forth. They perform their confinement function by being sealed structures (Containment) without reliance upon air motion and filtration to manage the spread of radioactive material. The primary confinement is contained within the process bays and the RLW room. A rupture of the primary confinement will allow a release into the secondary confinement volume. The spread of contamination from an accidental release in the secondary confinement volume is managed by the HVAC system serving the space.

4.1.1.2.1 MCO Release Collection. Primary confinement of releases that may occur in the vicinity of the top of the MCO shall be accomplished with a hood that will draw the air from the top of the MCO into a duct leading to the local exhaust system. The hood shall be custom designed with a minimum inlet face velocity of $125 \mathrm{fpm}$ per the requirement of DOE Order 6430.1A Chapter 11. The hood shall be mocked-up and smoke tested to verify its capture capability prior to fabrication and installation in the facility.

4.1.1.2.2 Local Exhaust System. A local exhaust system shall be provided to serve all the process bays. The primary exhaust system shall be a stand-alone system with $100 \%$ exhausted air. The local exhaust system shall serve all the MCO Process Hoods and the process system exhaust and vent streams that may normally be contaminated. All process inputs must be locally HEPA filtered before injection into the primary exhaust stream. The local exhaust system shall contain a HEPA filter train with a minimum of two HEPA filter stages. More stages may be used if safety analysis requires better filtration to achieve the offsite accidental exposure criteria.

\subsection{Secondary Confinement Ventilation System.}

- General Exhaust System. Each process bay shall be served by a general exhaust system that shall have sufficient capacity to ensure an adequate controlled ventilation flow as required to contain contamination in the event of a credible breach in the secondary confinement barrier. The system shall control air flow and maintain a minimum negative pressure differential of -0.05 in. w.g. in the bay with respect to its associated airlock and a minimum of -0.1 in. w.g. with respect to all other areas external to the secondary confinement barrier. Air from the transfer corridor, associated support rooms, and the mechanical room shall also be exhausted into the general exhaust system. Confinement isolation 
dampers shall be provided on all duct branches connecting to the general exhaust system to prevent back flow in the event of exhaust system shutdown. The air in the general exhaust system shall pass through a minimum of two HEPA filter stages before exhausting through the stack.

- Process Bay Supply System. Each process bay shall be served by a supply air system which recirculates a majority of the bay air to conserve energy. The recirculated air in the process bay supply system shall pass through a minimum of two HEPA filter stages to control contamination. Make-up air shall be supplied, as required, to maintain air quality in the bay and to provide air for the local exhaust system. The process bay air shall be continuously monitored for radioactivity. Detection of radioactivity in the process bay room air shall initiate an alarm. In the event of a radiation alarm, workers shall leave the area but the supply system shall continue to operate, recirculating air through the HEPA filters. Safety personnel shall determine if the supply system should be shut down.

4.1.1.2.4 Confinement During Facility Shutdown. The CVDF shall be designed to maintain adequate confinement defined as a condition that assures that accidental releases from the primary confinement that may occur during a facility shutdown do not result in unacceptable dose consequences to on-site workers or off site public. This is to be achieved by allowing the primary and secondary ventilation systems to go to an unpowered state where all openings in the building structure are either closed or blocked by HEPA filters. All secondary confinement supply air intakes and primary/secondary exhaust openings in the building must be equipped with backdraft dampers, isolation dampers, or HEPA filters that will block the flow of contamination out of the process building during a shutdown period.

4.1.1.3 Safety Classification of CVDF Structures, Systems, and Components. The safety classification criteria for CVDF HVAC Structures, Systems, and Components (SSCs) is given in Chapter 9 of this Design Basis Document. The application of the criteria to the CVDF SSCs yields the following classification:

Table 4.1.1.3-1. SSC Safety Classification.

\begin{tabular}{|l|l|}
\hline \multicolumn{1}{|c|}{ SSC Name } & \multicolumn{1}{|c|}{ Safety Classification } \\
\hline MCO* $^{*}$ & Safety Class \\
\hline Process Hood, Duct to the HEPA Filter, Exhaust HEPA Filter & Safety Significant \\
\hline Supply Air Backdraft Dampers and Exhaust Isolation Dampers & Safety Significant \\
\hline Stack & Safety Significant \\
\hline
\end{tabular}

*Not provided by the CVDF. 
The structural performance categorization as defined by DOE STD 1021 for the HVAC SSCs given in Table 4.1.1.3-1, as well as for items that have the potential for failure leading to damage of a safety class item are:

Table 4.1.1.3-2. SSC Structural Performance Categorization.

\begin{tabular}{|l|c|c|}
\hline \multicolumn{1}{|c|}{ SSC Name } & $\begin{array}{c}\text { SSC } \\
\text { Performance }\end{array}$ & $\begin{array}{c}\text { Anchorage } \\
\text { Performance }\end{array}$ \\
\hline MCO* $^{*}$ & & \\
\hline $\begin{array}{l}\text { Process Hood, Duct to the HEPA Filter, Exhaust } \\
\text { HEPA Filter }\end{array}$ & PC3 & PC3 \\
\hline $\begin{array}{l}\text { Supply Air Backdraft Dampers and Exhaust } \\
\text { Isolation Dampers }\end{array}$ & PC3 & PC3 \\
\hline Stack & PC3 & PC3 \\
\hline
\end{tabular}

*Not provided by the CVDF.

There are no safety class SSCs in the CVDF. There are safety significant SSCs that must function to assure that on site workers do not receive accidental doses in excess of the allowable limit. These are supply and exhaust isolation dampers. These components are required to close in the event of a loss of power and must meet the seismic performance criteria given in Sections 3.5.3 and 3.5.4 of this DRD.

4.1.1.4 Filtration. HEPA filtration or equivalent filtration systems will be used for areas handling potentially radioactive particulates to minimize the exposure to personnel or the environment. Exhaust ventilation systems will be provided with HEPA filtration to minimize the release of hazardous materials through the exhaust path (DOE Order 6430.1A, Section 1550-2.5.5). All HEPA filtration design and construction practices shall conform to the guidelines of ERDA 76-21, Chapter 4.

HEPA filters and housing shall be fluid seal type. They shall be equipped with local differential pressure readouts to monitor the loading of the filters.

The number of exhaust filtration stages will be sufficient to limit concentrations of airborne radioactive particulates released to the environment to less than the applicable limits at the point of discharge during all anticipated operating and design basis accident (DBA) conditions. The adequacy of the filtration system will be confirmed by safety analysis to ensure that airborne radioactive particulate concentrations are ALARA and do not exceed DOE Order 5480.1A requirements during abnormal, accident, and DBA conditions. Exhaust air treatment systems will contain a minimum of two stages of HEPA or equivalent efficiency filtration, as required by safety analysis. A HEPA filter will have a minimum start-up efficiency of $99.97 \%$ as evaluated by test in accordance with ASME N510. HEPA filters 


\section{HNF-SD-SNF-DRD-002 Rev 0}

will have a clean resistance pressure drop not to exceed 1 in. w.g. with a velocity of the air entering the filter of $250 \mathrm{fpm}$. HEPA filters will be constructed and acceptance-tested in accordance with ASME AG-1.

Air filtration units will be designed and located with appropriate radiation protection to maintain occupational doses ALARA during operations and maintenance and will be designed so that a tier of filters can be completely isolated from the ventilation system during filter element replacement. Air filtration units will be installed as close as practical to the source of contamination to minimize the contamination of the ventilation system ductwork (DOE Order 6430.1A, Sections 1300-11.2, 1550-99.0.2).

The air filtration unit design will allow for routine in-place testing of HEPA filtration systems as outlined in ASME N510 (DOE Order 6430.1A, Section 1300-3.6).

HEPA filtration systems will be designed with prefilters installed upstream of HEPA filters to extend the HEPA filters life.

Supply air systems will be provided with filters rated at a minimum of $85 \%$ efficiency (atmospheric dust spot) in accordance with ASHRAE 62.

4.1.1.5 General Supply System. The transfer corridor, associated support rooms, and the mechanical room shall be supplied with air from the general supply system. The air in this system shall not be HEPA filtered and shall be $100 \%$ outside air. A confinement isolation damper shall be provided on the air intake to prevent back flow of air to the outside in the event of system shutdown.

4.1.1.6 Administration Area HVAC System. The Administration Area shall be conditioned with air from a dedicated air handling unit for this area. Air shall be recirculated with a minimum of make-up air to maintain air quality and provide air for the change room and shower area exhaust system. Air from these areas shall be exhausted directly to the outside and not recirculated. To prevent possible contamination, air in the room connecting the Administration Area to the transfer corridor shall not be exhausted to the outside, but directed towards the transfer corridor and the HEPA filtered general exhaust system. Provide differential pressure monitoring between the Administration Area and the transfer corridor to ensure the correct direction of air flow. Provide alarm capability to signal an upset condition in the pressure differential between areas.

4.1.1.7 Energy Conservation. DOE Order 6430.1A requires that a Life Cycle Cost (LCC) analysis be performed as a basis for selection of the building(s) energy source. Given that the Cold Vacuum Drying System (CVDS) operational lifetime is only two years and that the majority of the facility air is being recycled, there is no justification for producing the formal (expensive) report specified in the order. As a matter of good engineering practice heating/ 
cooling load calculations shall be developed, but cost analysis and altematives analysis shall not be performed. Design conditions used shall be as follows:

- Latitude: $46^{\circ} 34 \mathrm{ft}$

- Longitude: $119^{\circ} .036$ in.

- Altitude: $476 \mathrm{ft}$.

- Prevailing Wind: NW

- Outdoor Design Temperatures: $+9{ }^{\circ} \mathrm{F}$ winter; $97^{\circ} \mathrm{F} \mathrm{db}, 67^{\circ} \mathrm{F}$ wb summer

- Indoor Design Temperatures: $72^{\circ} \mathrm{F}$ winter, $75^{\circ} \mathrm{F}$ summer.

4.1.1.8 Human Factors Considerations. An effective climate control system will be provided to maintain temperature and humidity at an acceptable level between the humans and the environment. Temperature and humidity tolerance limits for recommended comfort zones are provided in NUREG 0700, Section 6.1 and UCRL 25673, Section 3.2.4.5 (DOE Order 6430.1A, Section 1300-12-4.3), and GC CLIM-01.

Ventilation exhaust will meet the requirements of DOE Order 6430.1A, Section 1550-1.5.

Each control device will provide the appropriate control capability, range, and sensitivity for necessary control setting and manipulations. Control operating characteristics will conform with operator expectations. Control components will be durable, comparable with nontypical apparel where required, and not prone to accidental activation (DOE Order 6430.1A, Section 1300-12.4.7).

The design of equipment will incorporate the objective of efficient maintainability. The surveillance, testing, and maintenance of a system and its restoration to operational effectiveness will be achieved at minimum costs with a minimum level of support services (DOE Order 6430.1A Section 1300-12.4.10).

4.1.1.9 Access and Working Space. Sufficient access to and working space around HVAC equipment will be provided to permit ready and safe operation and maintenance of such equipment. Access and working space will be in accordance with supplier and International Conference of Building Officials Code requirements.

4.1.1.10 Environmental Regulations. Radionuclides, nonradioactive air pollutants and toxic air pollutants will be emitted through the exhaust stack. Radioactive air emissions and monitoring are governed by EPA regulations at 40 CFR 61 and the Washington regulations listed in WAC 246-247. Nonradioactive air pollutants are governed by the regulations listed in WAC 173-400. Toxic air pollutants (TAPs) are governed by regulations listed in WAC 173-460. All of these regulations specify emission limits and they require the use of emission control technology. 


\subsubsection{Reference Codes and Standards.}

1. GH-CLIM-01, Design Climate Data for the Hanford Site.

2. WHC-CM-7-4, Operational Environmental Monitoring.

3. WHC-S-0425, Rev. 0, Performance Specification for the Spent Nuclear Fuel Canister Storage Building, Rev. 0.

4. Federal Laws:

a. 40 CFR 61, National Emission Standard for Hazardous Air Pollution.

b. DOE Order 6430.1A, "General Design Criteria" (Dated April 4, 1989).

c. DOE/EV/1830-T5, "Guide to Reduction Radiation Exposure to ALARA."

d. DOE Order 5480.4, Environmental Protection, Safety, and Health Standard.

e. DOE Order 5820.2A, "Radioactive Waste Management."

5. ACGIH Industrial Ventilation Manual.

6. Air Movement and Control Association (AMCA).

a. Publication 99 , Standards Handbook.

b. Publication 201, Fans and Systems.

7. ASHRAE.
a. ASHRAE 15, Safety Code for Mechanical Refrigeration
b. ASHRAE 52, Method of Testing Air Cleaning Devices Used in General Ventilation for Removing Particular Material
c. ASHRAE 55, Thermal Environmental Conditions for Human Occupancy
d. ASHRAE 62, Ventilation for Acceptable Indoor Air Quality
e. ASHRAE 90A, Energy Conservation in New Building Design.

8. American National Standards Institute (ANSI)
a. ANSI/ASME N509, Nuclear Power Plant Air Cleaning Units and Components, 1980
b. ANSI/ASME N510, Testing of Nuclear Air Cleaning Systems 
c. ANSI/ASME NQA-1, Quality Assurance Program Requiremnts for Nuclear Facilities

d. ASME AG-1, Code on Nuclear Air and Gas Treatment, 1994.

9. Factory Mutual - Loss Prevention Data Sheet 1-45 "Air Conditioning Ventilation Systems."

10. International Conference of Building Officials.

a. Uniform Building Code (UBC)

b. Uniform Mechanical Code (UMC).

11. National Fire Protection Association.

a. NFPA 90A, Air Conditioning and Ventilation Systems

b. NFPA 91, Blower and Exhaust Systems

c. NFPA 45, Fire Protection for Laboratories Using Chemicals.

12. Nuclear Air Cleaning Handbook - ERDA 76-21.

13. Sheet Metal and Air Conditioning Contractors National Association (SMACNA)

a. HVAC Duct Construction Standard

b. Round Industrial Duct Construction Standard

c. Rectangular Industrial Duct Construction Standard

d. HVAC Systems - Duct Design.

14. Washington Administrative Code (WAC)

a. Air Pollution Control Regulation WAC 173-400; Regulations for the control of nonradioactive criteria air pollutants.

b. Radioactive Airborne Emission Standards WAC 246-247. Regulations for the control of radioactive air pollutants.

c. Toxic Air Pollutants Regulations WAC 173-460. Regulations for the control of air toxic air pollutants.

d. On-Site Sewage Systems WAC 246-272. 


\subsection{HVAC DESIGN CONSIDERATIONS AND STANDARD PRACTICES}

\subsubsection{Calculation Methods}

Industrial ventilation design air quantities and transport velocities shall be calculated according to the calculation methods prescribed by the ACGIH Industrial Ventilation Manual, 29 CFR 1910 and NFPA 45, NFPA 90A, NFPA 91, NFPA 807, and UBC requirements.

\subsubsection{Ductwork and Dampers}

Design and installation of ductwork and dampers shall comply with DOE Order 6430.1A Section 1550-2.5.6 which requires compliance with NFPA 90A and SMACNA. Ducting systems shall be designed to minimize pressure drops through the system while maintaining the required entrainment velocities. Fire dampers will be provided in all supply return and exhaust air duct penetrations of fire rated walls. Provisions shall be included for testing of dampers.

- Exhaust ducts shall be sized for the transport velocities needed to convey all particulate without settling. Velocities shall be determined per Section 5 of the ACGIH Industrial Ventilation Manual. Duct thickness shall be determined by Tables 5.1, 5.2, 5.3 and 5.4 of ERDA 76-21. All welded ductwork shall have a minimum duct thickness of No. 16 U.S. gage.

- All ducting systems shall be classified as determined by the criteria of the ERDA 76-21 Table 5.5. Each duct system shall comply with the design and construction standards specified in ERDA 76-21 for the levels determined from Table 5.5. Acceptable leakage for each level of classification shall be no greater than the limits specified in Table 5.6 of ERDA 76-21.

- Round ductwork or pipe shall be used for the confinement exhaust system ventilation unless its installation is impractical. Exhaust system duct velocities shall be maintained at a minimum of $2,000 \mathrm{fpm}$ to provide proper entrainment. Protective coatings shall be applied to the interior of exhaust ductwork serving the confinement areas if other than stainless steel ductwork is used. These coatings shall meet the requirements of ANSI N512 "light exposure."

- Duct maintainability and testability shall follow the guidelines outlined in the ERDA 76-21 Section 2.3.8. Duct clean-out provisions shall be included for all confinement ductwork. Adequate contamination control features and procedures shall be developed to perform duct clean-out operations. 
- Dampers shall comply with the requirements determined from Table 5.12 of the ERDA 76-21. Duct systems serving the confinement areas of the facility shall not be acoustically treated.

\subsubsection{Exhaust Stack}

An exhaust stack shall be provided for exhaust of all contaminated or potentially contaminated. The stack shall be directly monitored for alpha emitting particulates and indirectly monitored for beta/gamma emitting particles and gasses. The monitoring equipment shall allow for both local and remote readout and alarm annunciation. The stack monitoring system shall be provided with two monitoring systems which comply with DOE Order 6430.1A, Section 1589-99.0.1, "Radioactive Airborne Effluents," WAC-246-247-075, and ANSI N13.1, Guide to Sampling Airborne Radioactive Materials in Nuclear Facilities. Stack instrument requirements are given in Chapter 5 of this design requirement document (DRD).

\subsubsection{Exhaust Fans}

Exhaust fans shall use variable frequency controlled motors which receive control signals from exhaust flow and/or pressure measurements. Exhaust fan selection shall be based on the air change rates and pressure head calculated for the serviced areas or process cells. Results of the hazards analysis shall be used to determine the required air change rates. Fan selection shall consider all anticipated normal operation, up-set, off-normal, and transient conditions of the facility.

\subsection{PIPED SYSTEMS}

\subsubsection{General}

4.3.1.1 Introduction. The CVDF shall have mechanical systems consisting of supply and piping distribution subsystems which shall deliver fluids and gasses to process and facility functions. This section of the Design Basis Documents describes the requirements for these systems.

\subsubsection{References.}

- DOE Order 6430.1A Section 15 - General Design Criteria for Department of Energy Facilities.

- UBC. 
- ANSI/ASME B31.1, American National Standards Institute (FDC-4.3.2).

- ANSI/ASME B31.3, American National Standard Institute (FDC-4.3.2).

- SDC-3.2, Minimum Depth of Underground Water Lines.

- Compressed Gas Association Guidelines (CGA 1991).

\subsubsection{Water Systems}

4.3.2.1 Potable Water. Potable Water shall be supplied to the facility from an existing water main at the north side of the building near the $165 \mathrm{KE}$ Control Building. Potable cold water shall be used to supply the safety eyewashes, sinks, restrooms, custodial service sinks, and drinking fountains and decontamination shower. Hot water shall be supplied by two tank - type electric water heaters. There shall be no potable water lines in the process areas of the building except to serve eyewashes and safety showers.

The underground portion of the potable water supply shall be at a minimum depth as given by SDC-3.2.

4.3.2.2 Chilled Water Cooling System. A central facility Chilled Water Cooling System shall be designed to serve both ventilation cooling loads and process system heat exchangers. Chilled water shall not come in direct contact with process equipment surfaces (such as the $\mathrm{MCO}$ ) that might be contaminated. The system concept shall include a packaged chiller unit, circulating pumps, associated piping, instrumentation and controls. Make-up water shall be drawn from the potable water supply through a backflow preventer.

4.3.2.3 Deionized Water. Deionized water will be supplied to the process system via a packaged deionized water unit. The deionizer unit shall be sized for a minimum of $5 \mathrm{gpm}$. The deionizer shall feed a 250 gal plastic holding tank which will isolate the deionizer from possible contamination backflow and also will act as the process feed tank.

4.3.2.4 Water Plumbing. Potable water plumbing shall be conventional copper plumbing. Hot water and chilled water lines shall be insulated as appropriate for the surface to assure that the proper water temperature is delivered to the loads. Deionized water shall be distributed in polyvinyl chloride (PVC) plumbing.

4.3.2.5 Firewater System. The requirements for the firewater system are given in Chapter 8, "Fire Protection." 


\subsubsection{Sanitary Sewage Collection}

The CVDS will not be served by a sitewide sanitary sewage system. Sanitary sewage generated in the CVDS shall be collected in a holding tank at the CVDS and transferred to a pumper truck designed to transport sewage. A 5,000 gal tank shall be provided for sewage collection. Its elevation shall be such that it can be gravity fed. There shall be no connections to the sanitary sewage system in the process area of the CVDS. The sanitary sewer plumbing shall meet the standards of the Uniform Plumbing Code.

\subsubsection{Process Water Collection}

Drainage of each MCO that enters the CVDS will create approximately 150 gal of water with dissolved fission products and suspended spent nuclear fuel (SNF) corrosion particulate matter. Approximately an equal amount of rinse water will be used to flush radioactivity out of the process lines for each $\mathrm{MCO}$. Condensers in the process system will also generate some contaminated water. All the process water flows are to be collected into a central facility drain system which leads to a system of storage tanks and ion exchange columns. The contents of the storage tanks will periodically be pumped into a tanker truck designed to haul it to Hanford Radioactive Liquid Waste management facilities.

The process water collection (PWC) system piping shall be made from seamless 300 series stainless steel tubing or pipe with smooth interior surfaces. Large radius elbows shall be used. All joints shall be butt welded. Welds shall be radiographed. The PWC piping shall be designed and constructed to ASME B31.3 (Category M). The piping shall be uniformly sloped to assure that there are no points of hold-up in the system. Provision shall be made for filling the lines with decontamination chemicals or hydrolasing on a periodic basis. The PWC lines should be located so that they can be easily inspected. The PWC lines shall be shielded as determined appropriate by radiation exposure analysis. The shielding should be removable so that the lines can be inspected. Raw PWC shall be received in a critically safe tank (inside diameter $<23.5 \mathrm{in}$.). The transfer from the MCO in the process bays shall be driven by a vacuum drawn on the receiver tank. The evacuation draught shall be sufficient to draw water out of the $\mathrm{MCO}$ at a minimum rate of $5 \mathrm{gpm}$. The vacuum shall be created by a pump that is designed for service with wet air. The volume of the receiver tank shall be a minimum of $300 \mathrm{gal}$.

The contents of the receiver tank shall be filtered through a filtration / ion exchange column provided by others. Ion exchange column shielding and criticality control are the responsibility of those providing the column. There shall be provision for taking water samples from the receiver tank for analysis. The water shall be transferred to a large holding tank after the analysis has demonstrated that the water quality is acceptable for storage in a non-critically safe tank. The holding tank volume shall be determined by the limitation that simultaneous loss of the holding tank, receiver tank, and ion exchange column contents onto the floor shall not result in a non-critically safe geometry. The water depth on the floor shall not exceed 10 in. 
The room containing the PWC system shall be equipped with sensors to detect the presence of spilled water on the floor.

The holding tank shall be equipped with a pump, valves, and stainless steel braided hose to transfer the contents to a tanker truck. The shut-of valve shall be as close to the truck end of the hose as possible to minimize the quantity of water that could be spilled when the hose is disconnected when the transfer is complete. There shall be an air supply connected to the end of the hose to dry the connection zone before the disconnect action is taken.

The PWC system shall be constructed as a "skid" assembly. The frame, tanks, and mounts shall be considered to be safety significant SSCs and shall be designed according to the structural performance PC3 requirements (see Section 3.3.3 and 3.3.4).

All the tanks and piping in the PWC system shall be made of 300 series stainless steel. All welds shall be ground smooth on the interior. Seamless piping or tubing shall be used to eliminate entrapment of contamination on a rough weld inside the pipe. The interior surfaces of the tanks shall be polished to a \#4 dairy finish or better.

\subsubsection{Floor Drains and Firewater Collection}

Each bay and fire zone in the building shall be equipped with floor drains for the purpose of collecting firewater should the sprinkler system activate. The firewater shall be assumed to be possibly contaminated. All of the spill containment fire discharge water shall be routed in a double wall stainless steel piping system to an above ground retention basin located outside the facility. The piping shall be routed through a monitoring sump where the spill discharge occurrence shall be detected by a moisture sensor. The spill containment monitoring box will have a low discharge opening to drain the tank and a sump pump to transfer the collected liquid to a tanker truck. The basin shall have a minimum volume of $20,000 \mathrm{gal}$. The facility floors must have dikes and slopes, and the drain size must be designed, so that the build-up of water on the floor when the sprinklers are discharging at maximum rate cannot spill out of the CVDS. Firewater from HEPA filter deluge shall be routed into the floor drain system. Water from decontamination showers shall be routed into the floor drain system. 


\subsubsection{Instrument Air System}

Instrument shall be used to drive air-operated control valves and to provide air for general use with air operated tools. The air shall be provided by a compressor sized according to the following requirements:

- The delivery rate shall be determined by assuming that all air driven process valves and air driven HVAC dampers actuate simultaneously with the operation of a single air driven tool.

- The receiver tank size shall be adequate to supply air to activate all valves and dampers twice.

- Operating Pressure = 100 PSI.

Instrument air shall be free from oil and shall be dried to $-40^{\circ} \mathrm{F}$.

\subsubsection{Nitrogen System}

Nitrogen shall be distributed to the process bays for use as an MCO purge gas by the process system. Nitrogen shall be supplied from an LN2 dewar located outside the building where it can be accessed by delivery tanker trucks. The Dewar volume shall be sufficient to support the peak process rate of the CVDF for at least two weeks. Nitrogen gas shall be generated using an electrically heated vaporizer provided with the commercial Dewar package. The minimum delivery rate shall be 50 SCFM. The delivery pressure shall be 20 PSI.

Nitrogen piping shall be constructed from 300 series stainless steel tubing or pipe. The piping system shall have welded joints wherever possible. The system shall be pressure tested and bubble leak tested. Bottled gases and associated piping shall be in accordance with Compressed Gas Association guidelines (CGA 1991).

\subsubsection{Helium System}

Helium shall be distributed to the process bays for use as an MCO purge gas by the process system. Helium shall be supplied from a tube trailer located outside the building where it can be accessed by delivery trucks. The helium supply volume shall be sized to provide a minimum of two weeks peak process demand rate. The maximum delivery rate shall be 10 SCFM. The delivery pressure shall be regulated to 20 PSI.

Helium piping shall be constructed from 300 series stainless steel tubing or pipe. The piping system shall have welded joints wherever possible. The system shall be pressure 
tested and bubble leak tested. Bottled gases and associated piping shall be in accordance with Compressed Gas Association guidelines (CGA 1991).

\subsubsection{Safety Class Helium System}

There shall be a helium supply system that delivers helium to the MCO when specific accident conditions arise. This system shall be designed to be completely separate from the normal operations helium system (See Section 4.9). The safety class helium system shall be supplied by gas bottles stored within the CVDF facility in a seismically qualified rack. There shall be two independent sets of supply gas bottles located at different points in the facility so that they cannot be simultaneously damaged by a single missile. Two independent piping systems shall deliver the helium to the MCO connections in each process bay.

System components such as regulators and valves shall be qualified for performance during and after the Design Basis Earthquake (See Section 3.5.3).

Helium piping shall be constructed from 300 series stainless steel tubing or pipe. The piping system shall have welded joints wherever possible. The system shall be pressure tested and bubble leak tested. Bottled gases and associated piping shall be in accordance with Compressed Gas Association guidelines (CGA 1991).

\subsubsection{Vacuum System}

A Vacuum System shall provide a low pressure regulated airflow for the Health Physics (HP) instrumentation, and specifically the continuous air monitors (CAMs) and any fixed head filters.

The system shall have flow and pressure sensors that report the operating status to the control room. Exhaust from the vacuum system shall be directed to the Zone I exhaust.

\subsubsection{Breathing Air}

No central breathing air system is required. Operators will wear self-contained breathing apparatus (SCBA) units if an event requiring supplied air entry should occur.

\subsubsection{Piping}

A general concept shall be developed as a standard for each piping service. The standard design shall address the facility interface connection, valves, penetrations, seals, welds, material selections, instrumentation, hangers and supports. All piping shall conform to DOE Order 6430.1A, Section 15. All fittings, flanges and valves shall be in accordance 
with ANSI B16. Utility piping shall be designed and fabricated in accordance with ANSI B31.1. All hazardous chemical piping including those systems or components used for retaining or conducting radioactive products or contaminated waste shall be designed and fabricated in accordance with ANSI B31.3 (Category M).

\subsubsection{Safety Class Helium and Process Water Collection System Piping Mounting And Seismic Resistance}

Piping systems shall be mounted according to the guidance of WHC-SD-GN-30006 Section 3.3.8.

Piping supports shall be rigid members that are fastened to building structural members by bolted or welded joints. They shall surround the pipes so that pipes may not fall off the support in the event of an earthquake. Pipe supports shall not be rigidly attached to pipes as to restrain the motion of long runs of pipe.

Threaded and bell and spigot joints are not to be used. Welded and bolted flanged connections are acceptable.

Small piping or tubing ( 1 in. or less) shall not be used to support eccentric masses such as motor or air operated valves. Supports should be located at the locations of these eccentric masses. Supports shall not be placed on the valve operator without additional support of the valve body or the pipe immediately adjacent to the valve. The valve body and operator shall be supported on a common structure.

Expansion joints shall be laterally supported. Support spacing shall not exceed the distances given in Table 3.4 of WHC-SD-GN-30006.

No seismic analysis shall be required for piping systems where the weight of sections between supports is less than $20 \mathrm{lb}$ per Table 2.7 of WHC-SD-GN-30006. 
HNF-SD-SNF-DRD-002 Rev 0

\subsection{ELECTRICAL AND INSTRUMENTATION}

5.1 ELECTRICAL

\subsection{INSTRUMENTATION}


HNF-SD-SNF-DRD-002 Rev 0

This page intentionally left blank. 


\subsection{ARCHITECTURAL}

\subsection{GENERAL}

\subsubsection{Configuration}

The Cold Vacuum Drying Facility (CVDF) design concept is given in the Cold Vacuum Drying Facility Conceptual Design Report (WHC-SD-SNF-CDR-003, Rev. 0.) which generally describes the CVDS as follows.

The CVDF will be a facility constructed at the K Basin Site within a few hundred yards of the basins. It will have process bays in which transport trailers can be contained while the free water is drained and a Vacuum/Gas Purge Process dries the spent nuclear fuel (SNF). The CVDF will also have a support area where there will be a control room, change rooms, and other functions required to support and coordinate operations.

The CVDF will be a temporary facility. The planned duration to work off the entire $\mathrm{K}$ Basins SNF inventory is 2 years. Therefore the design lifetime for the facility is $\mathbf{5}$ years or less. The features of the CVDF given in the Conceptual Design Report (CDR) were selected with the intent of creating a structure that can be dismantled and recycled with relative ease or that can be reconfigured for an unspecified, future alternative use with relative ease. The concept utilizes a steel frame with attached panels to facilitate decontamination/dismantlement. The detailed design shall follow this philosophy.

The CVDF building will be a steel frame structure on a concrete pad located on the $\mathrm{K}$-Basin site. The site location is close to the K-Basins, near utility lines, and outside a nearby eagle roosting area. The conceptual building plans include multiple independent bays where transport trailers will be parked and processed. The number of bays was selected based on process time and the desired throughput. These bays are connected by a corridor. Truck access to each bay will be through overhead doors. The corridor allows personnel access through step off pads, as well as acting as a chase for service header piping and conduits. Personnel will enter the building through the support area at the end of the building where there will be facilities for changing, bathrooms, lunch, and control of the building activities. Bay walls will be precast concrete panels in order to provide shielding between the bays. Each bay will be served by a dedicated ventilation system that will circulate and high-efficiency particulate air (HEPA) filter the air, as well as exhaust process exhaust and vent streams and air collected from a hood at the top of the Multiple Canister Overpacks (MCO) where connections are made and broken. These exhausts are collected in a stack that will be monitored to detect radioactive emissions. Other mechanical systems that are distributed to each bay include chilled water, compressed air, firewater, radioactive liquid waste collection, and gasses. There will be no sanitary sewer connection to the CVDF. Sewage will be collected in a tank and transferred to a tanker truck that will haul it to a sewage treatment plant offsite. Radioactive liquid waste $(\mathrm{RLW})$ will also be collected in 
a tank, processed, and transferred to a tanker truck periodically. The RLW will be trucked to Hanford Radioactive Liquid Waste Processing facilities. The RLW and sanitary waste handling systems require space allotment within the CVDF that is accessible to trucks.

The features and configuration indicated in the CDR shall be the basic configuration implemented by the CVDF detail design.

\subsubsection{Design Criteria Documents}

Document Title

(Abbreviated)

Performance Specification for the

Cold Vacuum Drying Facility

Cold Vacuum Drying Facility

Conceptual Design Report

Standard Engineering Practices

DOE General Design Criteria

Minimum Design Loads for Buildings

and Structures

Uniform Building Code

1994

National Fire Protection Association 1990

OSHA Part 1910

\section{Reference}

Symbol/Number

WHC-S-0435 Rev. 0

January 8, 1996

WHC-SD-CDR-003

Rev. 0

WHC-CM-6-1

DOE Order 6430.1A 4-6-89

ASCE 7-88

UBC

NFPA-101

OSHA Subpart D

\section{Area of Coverage}

a. Performance requirements and basic design criteria

a. Defines CVDF features

a. Standards for Engineering Practices

a. General architectural, civil and structural requirements

a. Minimum Design Loads in Buildings and Other Structures

a. Building type classification and allowable areas for buildings and structures

b. Fire-resistive standards

c. Habitability, accessibility and life safety standards

a. Building - Life and Safety Codes

a. Guardrails, handrails, stair treads, ladders 
Document Title (Abbreviated)

AISI Specification for design of Cold Formed Steel Structural Members 1986 Edition

Federal Property Mgmt. Regulations 41 CFR 101-17

Standards for Surface Flammability of 16 CFR 1630 Carpets and Rugs

Aluminum Association

American Architectural Manufacturer Association

American Plywood Association

Ceiling and Interior Systems

Contractors Association

Exterior Insulation Manufacturers EIMA

Association

Insulated Steel Door Systems Institute

Metal Building Manufacturers

Association

National Association of Architectural Metal Manufacturers

National Roofing Contractors Association

Steel Deck Institute

Steel Door Institute

Sheet Metal and Air Conditioning Contractors National Association

Single Ply Roofing Institute

Steel Window Institute

Tile Council of America
AA

Reference

Symbol/Number

AISI

AAMA

APA

CISCA

ISDSI

MBMA

NAAMM

NRCA

SDI

SDI

SMACNA

SPRI

SWI

TCA

\section{Area of Coverage}

a. Light gauge cold formed steel design

a. Office space utilization

a. Fire-resistive Standards

a. Standards for Aluminum Finishes

a. Aluminum Window Standards

a. Performance Standards for Plywood

a. Use and Practices for Acoustical Ceilings

a. Guideline specifications for Exterior Insulation

a. Installation Standards for Steel Doors

a. Metal Building Design

a. Metal Finishes Manual

a. Roof Design

a. Roof Deck Design

b. Ceiling Deck Design

a. Steel Door Standards

a. Architectural Sheet Metal Manual

a. Roofing Design

a. Steel Window Specifications

a. Ceramic Tile Design 
Document Title (Abbreviated)
Reference

Symbol/Number

National Bureau of Standards, Product NBS

Standards

West Coast Lumber Inspection Bureau WCLIB

AWI

Architectural Woodwork Institute

National Electrical Manufacturers

Association

National Coil Coaters Association

Factory Mutual

Underwriters Laboratory

Washington Administrative Code

Dangerous Waste Regulations
NEMA

NCCA

FM

UL

WAC $173-303$ a. Lumber Standards

a. Finish Carpentry Standards

a. Electrical Equipment and Materials

a. Painting Requirements for Building Siding

a. Fire and Safety Requirements

a. Fire and Safety Requirements

a. Storage treatment and disposal of dangerous waste

\subsubsection{Occupancy}

The building code requirements shall be met as defined in the Uniform Building Code (UBC) for a Group H-7 occupancy for the process bay and support areas and Group B occupancy for the administrative office areas. Exiting requirements shall conform to the NFPA 101 Life Safety Code. The facility classification criteria shall also conform to requirements established in DOE Order 6430.1A, Section 0110-99 for special facilities (Nonreactor Nuclear Facilities) and Section 1320 (Irradiated Fissile Material Storage Facilities). All facilities shall be designed to support both sexes. For design purposes, the personnel requirements are as shown below:

- Single-shift operation (1.67 MCOs/week)

15 people

One 8-hour shift/day, 7 days/week, 15 employees/shift

- Three-shift operation (5 MCOs/week)

45 people

Three 8-hour shifts/day, 7 days/week, 15 employees/shift. 


\subsubsection{Special Architecture}

The architectural design of the facility shall be plain and unobtrusive with colors to match the existing WHC color scheme (white with blue trim). The design shall optimize the ease of dismantling the facility when its mission has been fulfilled.

\subsubsection{Handicapped Access}

The facility is exempt from accessibility requirements due to the operation requirements. However, the administrative office portion has been designed to be accessible with minor modifications.

\subsubsection{Decontamination Design}

The design of the facility and materials utilized shall conform to 10 CFR $835.1002 \mathrm{~d}$ as providing features allowing operations, maintenance, decontamination, and decommissioning.

\subsubsection{Future Facility Use}

The facility process has a scheduled life of approximately 2 years. The design and materials shall be adaptable and flexible in nature to allow for future reconfiguration or dismantlement.

\subsubsection{Egress Requirements}

150 feet shall be the maximum travel distance to any exit discharge per NFPA-101, Life Safety Code.

Doors shall be operable from the inside without excessive force and without keys or special knowledge.

Exitways shall be clearly marked and illuminated with at least 1 footcandle upon path of travel at all times.

Occupied spaces shall be suitably lighted and ventilated for safe habitation at all times. 
HNF-SD-SNF-DRD-002 Rev 0

\subsection{SPACE REQUIREMENTS}

\subsubsection{Process Bay Space Requirements}

Each process bay shall provide ground floor space for the following:

- Enclose a cask transporter without the tractor attached.

- Personnel circulation and functional space around the cask transporter.

- Seismic restraint hold-down devices at the front of the cask transporter.

- Vacuum drying module equipment and pump assemblies.

- Access to the working level of the cask transporter.

- Radiological control between a process bay and the access corridor where operators change clothing and are monitored for radiological contamination prior to admittance to the access corridor.

- Bridge crane access to remove the cask lid and perform maintenance on equipment.

- A cabinet for supplies.

Access to the working level of the cask shall be accomplished using a mezzanine level with space for the following:

- Access to the working level of the cask transporter for connections from the vacuuming model to the cask.

- Heating, venting, and air conditioning (HVAC) equipment.

- Process hood assembly.

\subsubsection{Process Bay Support Areas}

The process bay support areas shall serve as an airlock between the controlled process bay and the uncontrolled circulation corridor. Functional requirements for each process bay are:

- Seating space for two allowing for the dressing/undressing of Special Work Permit (SWP) clothes. 
- Storage of clean SWP clothing.

- Storage of dirty SWP clothing.

- Space for personnel contamination monitor (PCM) equipment.

\subsubsection{Personnel Decontamination Room}

A single decontamination room shall serve all process bays. Access is required prior to entering the common change room area. Requirements for this space are:

- Clear standing space for the decontamination process.

- Storage of decontamination materials and detection equipment.

- One decontamination shower.

\subsubsection{Swipe/Count Room}

A swipe/count room shall be provided to analyze and store samples taken from process bays or areas that have the potential for contamination. Requirements for this space are:

- Lab bench work space with desks and associated instrumentation equipment.

- A fume hood.

- Storage space for Health Physics Technician (HPT) equipment.

- Wall space for the mounting of gas bottle equipment.

\subsubsection{PWC Process/Handling Room}

Radioactive water removed from shall be collected, processed, and stored in tanks located in an isolated room with controlled access. This room shall be located directly adjacent to a process bay to allow a tanker truck to enter the bay and receive the transfer of liquid from the storage tanks.

\subsubsection{Miscellaneous Materials Storage}

A room shall be provided in the process area to store supplies. 


\subsubsection{Administrative Area}

An administrative area shall be provided to control personnel access into the CVDF and provide space for:

- Training/Conference Room

- Quality Assurance

- Shift Manager

- HPT/Radiation Monitoring

- Control Room

- Electrical/Telecommunications Room

- Fire Riser Room

- Men's and women's restrooms

- Men's and women's change rooms

- Access/egress control and personnel control monitoring of the process bays.

\subsubsection{Training/Conference Room}

A training/conference room is required with space for seating 12 people. Additional requirements are:

- Space for refrigerator.

- Casework with sink and storage.

\subsubsection{Quality Assurance Support}

Provide office space for two persons performing quality assurance duties.

- Work spaces with desks and associated equipment.

\subsubsection{Shift Manager}

Provide office space for one person performing shift management duties.

- Work space with desks and associated equipment.

\subsubsection{HPT/Radiation Monitoring}

Provide office space for one health physics technician to write reports, maintain records, and receive radiation alarms. 


\section{HNF-SD-SNF-DRD-002 Rev 0}

\subsubsection{Control Room}

Provide space for process bay control room functions.

- Computer monitoring stations.

\subsubsection{Electrical/Telecommunications}

Provide space for electrical/telecommunication systems and equipment.

\subsubsection{Fire Riser Room}

Provide space for mechanical fire riser equipment.

\subsubsection{Men's and Women's Restrooms}

Restroom facilities shall be provided for both men and women employees. This function should be in close proximity to the respective change rooms.

- Men's toilet and urinal fixtures.

- Women's toilet fixtures.

- Men's and women's lavatory fixtures.

\subsubsection{Men's and Women's Change Rooms}

Change room facilities shall be provided for both men and women employees. This function should be in close proximity to the respective restrooms.

- Men's shower facilities.

- Women's shower facilities.

- Men's and women's storage lockers and benches.

Space for change room supplies storage. 


\subsection{MATERIALS AND COMPONENTS}

\subsubsection{Doors and Windows}

6.3.1.1 Fire Doors. Fire doors shall be provided as required by the Fire Hazards Analysis, the Uniform Building Code, NFPA-80, and NFPA-101. In addition, all fire doors and frames shall meet all requirements of the Underwriters Laboratories and shall bear the Underwriters Laboratories (UL) or Factory Mutual (FM) label. Fire doors and frames shall be constructed from metal. Structural members, such as steel channels embedded in wall openings, shall not substitute as door frames. All fire doors shall be provided with fitted frames which are anchored to, but separate from, the building structural members. The fire doors shall contain windows fitted with UL approved fire resistant safety glass which is not removable from the outside of the door. Installation shall meet all the requirements of NFPA-80 and NFPA-101.

6.3.1.2 Exterior Doors. All exterior doors, except for the main administrative entrance door, shall be classified as an emergency egress door. All exterior doors and frames shall be constructed of metal. Structural members, such as steel channels embedded in wall openings, shall not substitute as door frames. All doors shall be provided with fitted frames which are anchored to, but separate from, the building structural members. All exterior doors separating heated spaces from the outside environment shall be fitted with UL approved double glazing and door frames insulated with UL approved insulating materials, which must meet fire rating requirements of the installation site. All exterior doors shall be connected to the facility security system. In addition, all exterior doors shall be provided with non-skid concrete landings.

6.3.1.3 Interior Doors. Doors which provide Zone II access, and selected egress doors shall be equipped with windows, and shall be equipped with automatic door closers. All interior doors shall be constructed of metal and shall be UL fire rated doors as required by code. All door frames shall be constructed of metal. Structural members, such as steel channels embedded in wall openings, shall not substitute as door frames. All doors shall be provided with fitted frames which are anchored to, but separate from, the building structural members. In addition, all of the interior doors, which contain windows, shall be fitted with fire-resistant, UL approved safety windows appropriate for their installation site.

6.3.1.4 Transporter Access Doors. All transporter access doors shall be telescoping type, fully weather-stripped, and shall be electrically operated with manual override. The use of "roll up" type doors shall be avoided as much as practically possible. The doors shall be designed to normally seal with minimal leakage with -0.1 in. differential pressure excluding wind load. 
6.3.1.5 Windows. Selected doors regularly used for egress shall be fitted with windows. The windows shall be fully tempered UL approved safety glass and sized in accordance with their intended function. All exterior windows shall be double glazed with tempered UL approved safety glass.

6.3.1.6 Hardware. A minimum of 1-1/2 pairs of ball bearing butt hinges shall be provided on all doors. Furthermore, all door hinges shall conform to the latest issue of Federal Specification FF-H-116 or ANSI-A156.1 and ANSI-A156.7. Fire exit doors and other emergency exit doors shall be equipped with panic hardware in accordance with NFPA-80 and NFPA-101. All doors requiring locks shall be provided with locks as authorized by DOE-RL. All lock and latch sets shall meet the latest issue of Federal Specification FF-H-106 or ANSI-A156.2. Kick plates, 12 inch by door width, shall be provided on all doors as required.

\subsubsection{Concrete Tilt-up Panels}

All masonry and concrete design shall comply with current UBC standards, American Concrete Institute (ACI), and Precast Concrete Institute (PCI) standards.

\subsubsection{Metals}

6.3.3.1 Interior Metal. All interior unpainted metal trim, hardware, cabinets, coverplates, etc., shall be polished chrome, polished stainless steel, or anodized aluminum. All painted metal trim, coverplates, etc., shall be painted with an approved enamel or epoxy based paint suitable for the use and environment.

6.3.3.2 Exterior Metal. All exterior metals to be painted shall be primed and painted in accordance with the standards developed by the National Association of Corrosion Engineers (NACE) and the National Paint and Coating Association (NPCA). All color schemes shall match the existing Westinghouse Hanford Company (WHC) color scheme.

\subsubsection{Plastic}

6.3.4.1 Interior Plastic. Interior trim materials fabricated from plastic shall have a matte finish and the colors shall be coordinated with the interior color scheme. Materials of construction shall be limited to those known to exhibit flame retardant properties, and which minimize the production of toxic or otherwise hazardous smoke or particles if ignited.

6.3.4.2 Exterior Plastic. Exterior trim materials fabricated from plastic shall have a matte finish and the colors shall be coordinated with the exterior color scheme. 


\subsubsection{Moisture And Thermal Barriers}

\subsubsection{Waterproofing. Not applicable.}

6.3.5.2 Insulation. Insulation shall be provided at the roof and walls of heated areas. Rigid insulation shall be provided at foundation perimeter around administrative office area at a minimum of 24 in. below grade. Insulation shall comply with the provisions of "DOE-RL Architectural Engineering Standards," Section 5.3.6. Vapor barriers shall be provided on the interior of exterior walls and interior partitions adjacent to conditioned spaces which require humidity control.

\subsubsection{Roofing}

Roof and ceiling insulation shall be approved for UL class A and FM class 1 installations. Roofing shall comply with UBC Chapter 15 for roof construction and covering and UBC Chapter 16 for roof and wind design. The exterior roof of any of the secondary confinement area shall not leak water at $0.1 \mathrm{in}$. w.g. internal secondary pressure. The minimum roof slope shall be $1 / 4 \mathrm{in} . / \mathrm{ft}$.

\subsubsection{Exterior}

\subsubsection{Exterior Insulation and Finish System. Not applicable.}

6.3.7.2 Exterior Siding. The exterior wall system shall be selected from the variety of wall systems available that offer advantages of cost, simplicity of erection, flexibility, maintainability, and diversity of color and texture.

6.3.7.3 Flashing and Sheet Metal. Flashing shall be specified over doors, outside openings, and all wall and roof penetrations.

\subsubsection{Joint Sealants}

Careful selection of materials, methods, and detailing of joints is required to eliminate water penetration and air infiltration of the building envelope. Caulking and sealant is required in cracks or joints in exterior walls to make the building airtight or watertight. A single moisture medium modules silicone sealant is preferred for use on metal and glass surfaces. A polyurethane sealant is preferred for use on concrete surfaces. 


\subsubsection{Special Coatings}

6.3.9.1 Exposed Concrete. When exposed concrete comprises the finished material, consideration shall be given to the quality and appearance of the final surface finish and form tie holes. Where appropriate to the design, the form work shall be carefully designed and detailed. Concrete surfaces within the process bays including the floor and a $4 \mathrm{ft}-0 \mathrm{in}$. height wainscot on the pre-cast wall faces shall be prepared to meet requirements for application of a decontaminable coating.

6.3.9.2 Engineered Design Features. Engineered design features shall include the use of specific materials and finishes to facilitate decontamination of walls and floors in all areas of confinement. The CVDF shall be designated as an Irradiated Fissile Material Storage Facility and shall meet the applicable requirements of DOE Order 6430.1A, Section 1320, and additional requirements contained herein.

6.3.9.3 Access Way Construction. Access way construction materials, i.e., gypsum board, wood, concrete, etc., must be completely covered with a sealant to reduce the surface permeability to air penetration. All construction cracks and joints shall be therefore sealed shut with non-shrinking sealant compound.

6.3.9.4 Finishes. Finishes and exposed joint patterns shall de designed to complement and be an integral part of the facility design.

\subsubsection{Interior Walls}

Interior walls surrounding and separating the process bays shall be constructed of pre-cast concrete panels capable of providing shielding protection of potential radiation sources. Similar panels shall be used to provide shielding around the process water tank room. All other interior walls shall be painted gypsum board over steel studs.

\subsubsection{Flooring}

Except for the process bays, floors throughout the facility shall have finishes appropriate to the area's function and flexibility requirements. In the process bays, exposed concrete floors shall have a clear $100 \%$ solid epoxy surface that can be easily decontaminated.

\subsubsection{Painting}

6.3.12.1 Exterior. Ferrous metals shall have one coat of metal primer and two coats of enamel. Galvanized metal shall have one coat of primer and two coats of enamel. 
Prefinished, metal panel surfaces shall not be painted. All paints or coatings shall be compatible with the building color scheme.

6.3.12.2 Interior. Metal surfaces shall have one coat of primer and two coats of enamel. Steel doors and door frames shall have one coat of primer and two coats of enamel. Exposed ductwork shall be painted with epoxy or enamel. All paints or coatings shall be compatible with the building color scheme. Painted surfaces within the secondary confinement area shall use finishes which are easily decontaminable.

6.3.12.3 Exposed Concrete. Not applicable.

\subsubsection{Specialties}

Toilet accessory systems and change room furniture shall be provided as necessary.

\subsubsection{Signage}

An integral system of internal and external building signage shall be incorporated in the facility design. Graphics shall be in Helvetica Medium type face.

\subsubsection{Conveyance System}

Each bay shall include an overhead bridge crane with a capacity of $4,000 \mathrm{lb}$. The crane shall be designed in accordance with the criteria included in CMAA 70. The bridge, trolley, and hoist shall be driven by electric motors and be capable of operation from the ground floor or mezzanine level. 
HNF-SD-SNF-DRD-002 Rev 0

7.0 PROCESS 
HNF-SD-SNF-DRD-002 Rev 0

This page intentionally left blank. 
HNF-SD-SNF-DRD-002 Rev 0

8.0 FIRE PROTECTION

8-1 


\section{HNF-SD-SNF-DRD-002 Rev 0}

This page intentionally left blank. 


\subsection{SAFETY}

\subsection{SCOPE}

The design of the Cold Vacuum Drying Facility (CVDF) shall specifically address protection of the environment, the public, and operations personnel by means of engineered safety systems, environmental monitoring systems, and safety assessment of the design and proposed operations. Environmental and public safety assessments shall include analysis of both normal operational conditions and postulated off - normal/accident scenarios.

A Preliminary Safety Evaluation (PSE) (WHC-SD-SNF-PSE-003 Rev. 0) has been completed in conjunction with the development of the Conceptual Design Report (CDR). This will be accomplished by applying technical requirements of applicable U.S. Department of Energy (DOE) regulations and requirements augmented by specific U.S. Nuclear Regulatory Commission (NRC) requirements deemed applicable to the CVDF. Other design guidance documents designated as "Applicable Documents" in Section 2.0 of WHC-S-0435, Performance Specification for the K Basin SNF Low Temperature Vacuum Drying Module, will be used as general reference and background documents except where specifically required by DOE Order, formal CVDF Project Management direction, or as called out in other sections of this Design Basis Document. The CVDF design will include features which ensure capability of compliance with OSHA regulations during construction and operation.

\subsection{CODES AND STANDARDS}

Codes and standards specific to the various design areas (e.g., Mechanical, Architectural, Structural, Heating, Venting, and Air Conditioning [HVAC], etc.) are given in the corresponding sections of this Design Basis Document. The following are documents which will be utilized in ensuring safety of design:

Document Title

Westinghouse Hanford Company Safety

Analysis Manual, "Safety Classification

of Structures, Systems and Components"

Safety Manual

Performance Specification for the K Basin SNF Low Temperature Vacuum Drying Module

Preliminary Safety Evaluation for the Spent Nuclear Fuel Project's Cold Vacuum Drying System

Nuclear Safety Analysis Reports

Natural Phenomena Hazards Mitigation
Symbol/Number

WHC-CM-4-46, Chapter 9, October 9, 1996

WHC-CM-1-10

WHC-S-0435, Rev. 0, January 12, 1996

WHC-SD-SNF-PSE-003, Rev. 0, May 1996

DOE Order 5480.23

DOE Order 5480.28 
Document Title

General Design Criteria

Preparation Guide for U.S. Department of Energy Nuclear Facility Safety Analysis Reports
Symbol/Number

DOE Order 6430.1A 1989

DOE-STD-3009-94 1994

The DOE has determined that it should be designed and built to achieve an affordable degree of safety as near as possible and affordable to that of a new facility designed to NRC standards. This "NRC equivalency" will be achieved through implementation of guidance from the following documents as formally directed by CVDF Project Management:

Document Title

Letter, E. D. Sellers, RL, to President, WHC, "Approval of the Spent Nuclear Fuel Project Regulatory Requirements Documents-Nuclear Regulatory Commission Equivalency"

Spent Nuclear Fuel Project Path Forward, Additional NRC Requirements
Symbol/Number

DOE Letter 96-SFD-003

January 10, 1996

WHC-SD-SNF-DB-003, Rev. 2 March 1996

\subsection{SAFETY DESIGN PHILOSOPHY}

The safety of the public and the worker, and the protection of the environment shall be the primary considerations in the design, construction, startup and operation of the CVDF. The CVDF design includes the means to protect the public, worker, and equipment from any hazards associated with the operation of the facility. Startup and operations shall maintain the CVDF within its safety authorization basis and shall be conducted in full compliance with applicable Federal, State, and local laws and regulations. Operations are to be conducted efficiently. No lost time accidents shall be a primary goal.

Exposures to radiation and toxic materials shall be held as low as reasonably achievable (ALARA) consistent with good industry practice and DOE Orders.

\subsection{SAFETY CLASSIFICATION}

CVDF structures, systems, and components shall be classified by safety class in accordance with the requirements of WHC-CM-4-46, Safety Analysis Manual (WHC 1996) Chapter 9. The safety classification determines structural and mechanical design criteria and ability to withstand Design Basis Accidents (DBA) including naturally-occurring phenomena. 


\subsection{SAFE SHUTDOWN}

\subsubsection{General}

The CVDF shall be designed to be safely shutdown in the event of a DBA or other stimuli deemed appropriate by the designer as required by Division 13 of DOE Order 6430.1A. The safe shutdown condition shall be one that assures that radioactive emissions from the facility do not exceed the allowable exposure limits.

\subsubsection{Safety Analysis Verification}

Safety analysis shall analyze the performance of the shut down facility when it is subjected to postulated credible events to determine that the off site and onsite exposure limitations are achieved.

\subsubsection{Passive Shutdown}

The CVDF shall be designed to shutdown safely without the use of an emergency power supply. The processes shall be designed to revert to a safe state upon loss of power. Uninterruptible power shall be supplied to control devices for the period of time that they are needed to function while the systems are achieving the safe shutdown state.

\subsubsection{Safety Classification of Structures, Systems, and Components Required to Achieve and Maintain the Safe Shutdown State}

Structures, Systems, and Components (SSCs) that must function in order to achieve the transition to the safe shutdown state or in order to maintain the CVDF in the safe shutdown state are safety class. They must be designed to function should the DBA for which they were designed occur.

\subsection{RADIOACTIVE MATERIAL CONFINEMENT}

\subsubsection{General}

The CVDF shall have two levels of confinement. The primary confinement system shall consist of the Multiple Canister Overpacks (MCO) and the process piping connected to the MCO and the Process Water Conditioning System. The primary confinement system shall be a barrier that separates the radioactive material contained in the $\mathrm{MCO}$ and the process piping from spaces bounded by structures whose failure would offer a path for a radioactive release into the CVDF or into the stack stream. The primary confinement shall 
be surrounded by structures and systems designed to confine radioactive material that may be released from the primary confinement in the event of an operational occurrence such as a small release when disconnecting the process lines from the MCO, or an accident. The secondary confinement shall protect the environment and people outside the building. The secondary confinement must withstand the effects of Design Basis Accidents including natural phenomena so that it achieves its required release mitigation performance should one of these

events occur. The CVDF building has been designed to withstand the Design Basis Tornado and Design Basis Earthquake so that it will not become a source of falling items or missiles that could threaten secondary confinement.

\subsubsection{Primary Confinement Integrity}

The primary confinement shall be the MCO and the process lines connected to the MCO. The primary confinement shall be designed to structurally withstand Design Basis Accidents as follows:

A. The MCO vessel shall be protected from failure due to over pressurization by a 150 PSI rupture disk. The primary confinement will be breached if the rupture disk is damaged or if it is actuated.

B. The process bay structure shall be designed so that it cannot fail in a manner that would allow any components to fall on the MCO top.

C. The primary process piping shall be supported by structures so that the piping will not break or open at joints. Calculations shall include all combinations of loads. The calculations shall determine that pipes will not break, hangars will not break, or any other structural failure will not release radioactivity outside the primary confinement.

D. The primary confinement shall be helium leak tested when installed and periodically thereafter. Process connections to the MCO shall be helium leak tested each time that they are made.

\subsubsection{Primary Confinement Leak Management}

The primary confinement internal pressure shall be kept slightly positive at all points in the system to ensure outward leakage if there are undetected leaks during MCO water removal and gas recirculation modes. During vacuum pumping the system will be monitored for pressure increases due to air inleakage or excessive pressure rise due to hydrogen accumulation. This scheme shall prevent the in flow of air when the process is active. 


\subsubsection{Secondary Confinement}

The secondary confinement structure shall be the Process Bays and Process Water Tank Room structures including parts of the secondary confinement ventilation system. Structural analysis shall demonstrate that the structure and ventilation system boundaries will not fail as a result of Design Basis Accidents loads. The secondary confinement shall meet the Performance Category 3 (PC3) structural criteria.

The process water tank room and each individual process bay shall be tested for leak rate in accordance with ASTM E-779-87, Standard Test Method for Determining Air Leakage Rate by Fan Pressurization. The test shall be conducted to determine whether the natural air infiltration rate is $\leq 0.3$ air changes per hour using the Lawrence Berkeley Laboratory (LBL) model (ASHRAE Handbook of Fundamentals) for calculating effective leakage areas and estimated natural infiltration rates. Infiltration leakage sources will be identified and sealed and the building retested until the $\leq 0.3$ air changes per hour criterion is met.

\subsubsection{Secondary Confinement Ventilation}

The secondary confinement shall be ventilated so that its interior volume is held at a negative pressure under normal operation. The negative pressure is not required when there is a loss of normal operating power or Design Basis Earthquake event. The secondary confinement ventilation air shall be exhausted through a dual stage HEPA filter. The isolation dampers, duct and filter housing shall be part of the secondary confinement structure.

\subsection{DESIGN BASIS ACCIDENTS}

The CVDF shall be designed to withstand the effects of design basis accidents, as delineated in DOE Order 6430.1A, General Design Criteria (DOE 1989), and DOE-STD-3009-94, Preparation Guide for U.S. Department of Energy Non-reactor Nuclear Facility Safety Analysis Report (DOE 1994), with confinement of radioactive and toxic materials within allowable limits. All Safety Class items, and Safety Significant items required to protect Safety Class items, shall withstand the DBAs.

The CVDF shall be designed, constructed, and operated such that after a design basis accident, potential exposure to radiation shall be within regulatory requirements. DBAs will be as identified below unless modification is required based upon safety analyses performed.

\subsubsection{Design Basis Fire}

There is no identified fire hazard and therefore no design basis fire for the CVDF. 


\subsubsection{Design Basis Power Failure}

The design basis power failure shall be considered to be a total loss of normal power (no electrical power from sources outside of the CVDF) for a maximum period of 24 consecutive hours. All Safety Class and Safety Significant active components shall be evaluated for fail-safe performance requirements. The adequacy of the final containment and confinement barriers shall be evaluated against the design basis power failure.

\subsubsection{Design Basis Earthquake}

CVDF SSCs shall be designed to withstand the effects of seismic events. Earthquake load for Design Basis Earthquake (DBE) is defined by design spectra representing seismic ground motions at the surface. These spectra are associated with horizontal peak ground accelerations defined in WHC-SD-SNF-DB-010, "Cold Vacuum Drying System Natural Phenomena Hazards."

\subsubsection{Design Basis Wind}

CVDF SSCs shall be designed to withstand the wind loading according to the requirements of WHC-SD-SNF-DB-010, "Cold Vacuum Drying System Natural Phenomena Hazards."

\subsubsection{Design Basis Tornado}

Although no design basis tornado missiles are considered credible for the CVDF, tornado wind loading shall be applied to SSCs in accordance with WHC-SD-SNF-010, "Cold Vacuum Drying System Natural Phenomena Hazards."

\subsubsection{Design Basis Flood}

The elevation of the CVDF site has been determined to be above the maximum extent of the Design Basis Flood Level (DBFL) and is not subject to regional flood hazards. However, the CVDF facility roof and site drainage systems may be subjected to rainfall which may cause local flooding. The local flooding shall be applied to the CVDF SSCs in accordance with WHC-SD-SNF-010, "Cold Vacuum Drying System Natural Phenomena Hazards." 


\subsubsection{Volcanic Eruption Considerations}

The CVDF is located in a geographic region where volcanic action may affect operation. The design of SSCs shall consider ash resulting from volcanic eruption according to WHC-SD-SNF-010, "Cold Vacuum Drying System Natural Phenomena Hazards."

\subsubsection{Design Basis Helicopter Crash}

Helicopters are used infrequently at the Hanford Site, safety analysis (WHC-SD-SNF-RPT-004, Chapter 1) has demonstrated that the risk associated with a site security helicopter crash is acceptable. Therefore, specific design features will not be incorporated to mitigate this accident.

\subsubsection{Design Basis MCO Flammable Gas Ignition}

The CVDF shall be designed to preclude a flammable gas ignition event within the MCO. The design of the SSCs for this event shall be Safety Class.

\subsubsection{Other Design Basis Accidents}

All DBA's identified by the revised preliminary hazard analysis (PHA) including internally generated missiles and blast effects, will be evaluated and taken into account in the design of the CVDF.

\subsection{SEISMIC CRITERIA}

The CVDF shall be designed to Performance Category 3 (PC-3) standards as defined in DOE Order 5480.28. The design of SSCs shall be according to WHC-SD-SNF-010, "Cold Vacuum Drying System Natural Phenomena Hazards."

\subsection{NUCLEAR CRITICALITY SAFETY}

The CVDF design shall comply with DOE Order 5480.24, Nuclear Criticality Safety, as implemented by WHC-CM-4-29, Nuclear Criticality Safety. The CVDF design will maintain criticality safety mandated spacing requirements during all DBA's. 


\subsection{SHIELDING CRITERIA}

DOE requires that the maximum annual exposure to an individual from all sources must not exceed a cumulative $1,000 \mathrm{mrem}$, summed over all controlled access areas. Hanford Site requirements are that the maximum annual exposure to an individual from all sources be less than 500 mrem (HSRCM-1, Hanford Site Radiological Control Manual, Rev. 2, 11/16/95). CVDF spaces must be designed to not exceed occupational dose limits in 10 CFR 835.202. Shielding designs shall be made ALARA in accordance with 10 CFR 835, Occupational Radiation Protection.

\subsection{ALARA CRITERIA}

\subsubsection{ALARA Definition}

As Low As Reasonably Achievable (ALARA) shall be a designed in operating principle to limit personnel and environmental exposures to the lowest level commensurate with sound economic and social considerations. ALARA shall mean conducting activities such that exposures to radiation are reduced to the lowest practical levels, considering the possible means of exposure reduction and the associated cost. The ALARA principle shall also apply to radioactive material releases to the environment and to both collective and individual doses.

\subsubsection{Physical Controls}

The primary means of achieving ALARA doses shall be through physical controls such as shielding, automation to reduce exposure time, remote operations, equipment arrangement, and nuclear material confinement.

\subsubsection{Engineering Controls}

Engineering controls that should be considered to achieve ALARA goals include:

A. Confinement systems such as process piping, vessels and structural enclosures.

B. Ventilation systems that assure negative pressure and flow toward the areas with highest contamination risk.

C. Compartmentalization to isolate higher risk areas.

D. Equipment location and arrangement so that servicing and replacement can be accomplished away from high risk areas. 
E. Waste treatment and handling systems to minimize releases.

F. Inclusion of decontamination features.

G. Automation of the process so that operators do not need to be present in the radiation field in order to operate the process.

H. Design the arrangement so as to maximize the distance between operators and sources.

I. Minimize traps where radioactive material can accumulate in the systems and also include provision for periodic decontamination of the process system.

\subsubsection{Maintenance Features}

The following maintenance features should be considered to reduce exposure of personnel:

A. Use modular construction to speed replacement.

B. Provide for decontamination before beginning a replacement. Use ease of decontamination as a consideration when selecting equipment.

C. Improve system performance to reduce maintenance requirements.

D. Select components that do not require lubrication or regular service.

\subsection{RADIOACTIVE CONTAMINATION CONTROL}

\subsubsection{Philosophy}

The strategy to control the spread of radioactive contamination within the CVDF shall include trapping radioactive material that could become entrained in $\mathrm{MCO}$ gas flows within filters inside the $\mathrm{MCO}$, trapping volatile radioactive $\mathrm{Cs}$ and $\mathrm{I}$ as close to the process stream exit from the $\mathrm{MCO}$ as possible, establishment of ventilation schemes to capture airborne radioactive material releases, planning for decontamination of process systems where contamination cannot be avoided, and detection of releases and contamination. The focus shall be on the connections at the top of the MCO that must be made and broken. These will necessarily be contaminated when they are separated after the drying process is complete. 


\subsubsection{Zoned Ventilation System}

The ventilation system shall be designed to assure that flow is from areas with the least potential for contamination to the area with the greatest likelihood for contamination. Negative pressure shall assure that air leakage flows from outside the process bays into the process bay areas and process water tank room. The negative pressure shall extend into the operations areas where personnel are also. Potentially contaminated air shall be withdrawn from the top of the MCO and exhausted through the ventilation system rather than releasing it into the bay.

\subsubsection{Contamination Release Detection}

Detection of released contamination shall be paramount to taking personnel protective actions and decontamination action. The design shall provide for the following detection methods:

A. Continuous Air Monitors (CAMs) shall be provided in the process areas where releases may occur.

B. The process bays and process water tank room shall have internal CAMs. The internal CAM shall be used to inform the operator that a contamination release requiring investigation before entry into the bay or tank room.

C. Routine swipe tests and counts shall be performed in areas of likely contamination. Provisions for testing shall be provided as part of the design.

D. Personnel self monitoring equipment shall be provided in the work area. Personnel shall be monitored by survey instruments in the entry ways to the CVDF process area.

E. The exhaust stack shall be continuously monitored to determine radioactive airborne effluent.

\subsection{INDUSTRIAL SAFETY AND HYGIENE}

\subsubsection{Industrial Safety}

The designer shall evaluate required codes, standards, and regulations for industrial safety. The designer shall identify any potential hazards to the health and safety of construction workers, operating personnel, and the public, or which present a risk of significant program interruption. In matters of design, the safety and health of the building 
occupants shall take precedence over other aspects such as function, cost, or expediency. The designer shall include the following features for personnel safety as a minimum:

A. Observance of emergency egress requirements for a hazardous facility.

B. Mechanical guards for exposed machinery.

C. First aid station, eyewashes, and safety showers.

D. Clearly identified load ratings and certifications for lifting equipment. Test capability for these items.

E. Clear identification of hazards by the use of signs or indicators.

F. Facilities for dispensing protective clothing and respirators.

G. Hazards detection and alarms systems.

H. Design floor load limits posted for nongrade areas.

I. Walking, driving, and working surfaces clearly designated for safety.

J. Adequate storage areas for plant supplies, materials, equipment to preclude housekeeping problems.

K. Safety interlocks for moving equipment to provide for personnel safety.

L. Emergency - off buttons for the process system easily available to plant operators.

\subsubsection{Industrial Hygiene}

The purpose of the industrial hygiene program shall be to anticipate and recognize health hazards arising out of operations and processes, and to control the hazards. The CVDF shall be designed to maintain employee exposure to these hazards at a minimum. The design shall ensure that personnel exposure to chemical and physical agents shall not exceed the limits listed in the American Conference of Governmental Industrial Hygienists (ACGIH) latest threshold limit value (TLV) booklet. The design shall ensure that the use of personnel protective equipment (e.g., respirators, hearing protection) shall not be required for normal operations. The hazards to be considered shall include chemical, physical, and ergonomic:

A. Chemical Hazards: These include excessive airborne concentrations of mists, vapors, gasses, or solids that are in the form of dusts or fumes. 
B. Physical Hazards: These include excessive noise, vibration, and nonionizing radiation as well as extremes of temperature and pressure.

C. Ergonomic Hazards: These include improper reaching or lifting situations, poor visual conditions, or repeated motion in awkward positions.

\subsection{INCORPORATION OF SAFETY INTO DESIGN AND OPERATION}

The assumptions and results of safety analyses performed for the CVDF will be incorporated into the facility's design documentation through formal assignment of all structures, systems, and components (SSC) to safety classes according to criteria based on potential consequence of failure. This assignment of safety class will be performed in compliance with the requirements of WHC-CM-4-46 and with the cooperation of the Design Agent. The safety classification of SSCs will be appropriately reflected in equipment specifications, system descriptions, operating instructions, test procedures, and other design media (approved for construction drawings). Safety Class and Safety Significant items shall be identified wherever they are depicted or listed in design documentation.

The Preliminary Safety Evaluation for CVDF requires that SSCs whose failure could prevent safety-class or safety-significant SSCs from adequately performing their safety function, either by loss of control or monitoring function or by damage through physical interaction, are classified in correspondence with the SSC being protected. 
HNF-SD-SNF-DRD-002 Rev 0

\subsection{SYSTEMS ENGINEERING}


HNF-SD-SNF-DRD-002 Rev 0

This page intentionally left blank. 
HNF-SD-SNF-DRD-002 Rev 0

\subsection{QUALITY LEVELS}


HNF-SD-SNF-DRD-002 Rev 0

This page intentionally left blank. 